\title{
Microbial methane oxidation and sulfate reduction at cold seeps of the deep Eastern Mediterranean Sea
}

\author{
Enoma O. Omoregie ${ }^{a, b, 1,{ }^{*}}$, Helge Niemann ${ }^{a, 2}$, Vincent Mastalerz ${ }^{c}$, Gert J. de Lange ${ }^{c}$, Alina \\ Stadnitskaia ${ }^{d}$, Jean Mascle $^{e}$, Jean-Paul Foucher ${ }^{f}$ and Antje Boetius ${ }^{a, b, g, *}$
}

\footnotetext{
a Max Planck Institute for Marine Microbiology, Bremen, Germany

b Jacobs University Bremen, Bremen, Germany

${ }^{c}$ Department of Earth Sciences, Utrecht University, Utrecht, The Netherlands

${ }^{d}$ Royal Netherlands Institute for Sea Research (NIOZ), Texel, The Netherlands

${ }^{\text {e }}$ Geosciences-Azur, Villefranche sur mer, France

${ }^{f}$ Department of Marine Geosciences, IFREMER Centre de Brest, Plouzane Cedex, France

${ }^{9}$ Alfred Wegener Institute for Polar and Marine Research, Bremerhaven, Germany

${ }^{1}$ Present address: School of Earth, Atmospheric and Environmental Sciences, The University of Manchester, Oxford Road, Manchester M13 9PL, UK. Tel.: +44 161275 5668; fax: +44 1613069361.

${ }^{2}$ Present address: Institute for Environmental Geosciences, University of Basel, Basel, Switzerland.

*: Corresponding author : Enoma O. Omoregie, Tel.: +49 4212028 860; fax: +49 4212028 690, email address : enoma.omoregie@manchester.ac.uk, Antje Boetius, email address : aboetius@mpi-bremen.de
}

\begin{abstract}
:
The Eastern Mediterranean hosts a variety of active cold seep systems, such as gas chimneys, mud volcanoes and pockmarks, in water depths of 500 to $3200 \mathrm{~m}$. As part of the NAUTINIL expedition in 2003, the sediments of cold seeps on the Nile Deep Sea Fan (NDSF) were sampled for the first time for biogeochemical and microbiological analyses. Here we compare rates of the anaerobic oxidation of methane (AOM) and sulfate reduction (SR) as well as the microbial community structure of a variety of cold seep systems including mud volcanoes, pockmarks and brine seeps. Our results revealed strong differences in microbial activity among the different seep systems of the Eastern, Central and Western provinces of the NDSF, as well as the Olimpi field (Central Mediterranean Ridge). Integrated over a sediment depth of $10 \mathrm{~cm}$ below the seafloor, SR rates ranged from $0.1-66 \mathrm{mmol} \mathrm{m}^{-2} \mathrm{~d}^{-1}$ and AOM rates from $0.1-3.6 \mathrm{mmol} \mathrm{m} \mathrm{m}^{-2} \mathrm{~d}^{-1}$. SR was often considerably higher than methane oxidation, indicating that electron donors other than methane were utilized. In general, the lowest rates were associated with pockmarks and carbonate pavements, and highest rates with bacterial mats above the gassy sediments of mud volcano centers. 16S rRNA gene analysis and fluorescence in situ hybridization (FISH), revealed the presence of all known groups of marine methane oxidizing Archaea (i.e. ANME-1, -2, -3) and also of methane oxidizing Bacteria (i.e. Methylobacter sp. and relatives) in some seep sediments. Presumably syntrophic sulfate-reducing bacterial partners of ANMEs were also detected in association with the ANMEs. Several ANMEs formed consortia with unknown bacterial partners. The microbial community structure reflected the presence of typical seep microorganisms at all sites investigated, but differed to varying extents between the different types of seeps. Despite the high availability of methane and sulfate, methanotrophic microbial activity and biomass were lower at the seeps of the Eastern Mediterranean compared to those of other continental margins for unknown reasons.
\end{abstract}

Keywords: methane oxidation; sulfate reduction; Archaea; cold seeps; mud volcano; pockmarks; Nile Deep Sea Fan 


\section{1. Introduction}

54 Cold seeps are geologically and geochemically active seafloor systems that often

55 host dense and diverse microbial and faunal communities fueled by fluid and gas

56 emissions to the sea floor (Sibuet and Olu, 1998; Treude et al., 2003; Levin, 2005;

57 Niemann et al., 2006a; Niemann et al., 2006b; Omoregie et al., 2008). A variety of such

58 cold seep systems, including mud volcanoes, pockmarks and brine lakes, have recently

59 been detected on the active ridges and passive continental margins of the Eastern

60 Mediterranean. Accumulations of fluid escape structures are found at the Eastern

61 Mediterranean ridge accretionary prism (Camerlenghi et al., 1992; Fusi and Kenyon,

62 1996; Woodside et al., 1998; Huguen et al., 2004; Huguen et al., 2005; Zitter et al., 2005),

63 the Nile Deep Sea Fan (NDSF) off the coast of Egypt (Mascle et al., 2001; Loncke et al.,

64 2004; Loncke et al., 2006; Dupré et al., 2007) and off the coast of Israel (Coleman and

65 Ballard, 2001). Due to the importance of methane as a greenhouse gas, increasing

66 attention has been given to the structure, function and distribution of cold seep

67 communities, which may act as a biological barrier to methane emission ((Hinrichs and

68 Boetius, 2002; Sibuet and Olu-Le Roy, 2002; Reeburgh, 2007) and references therein).

69 One of the main biogeochemical processes underlying energy flow in cold seep

70 ecosystems is the anaerobic oxidation of methane (AOM) via sulfate reduction (SR)

71 (Boetius et al., 2000a; Michaelis et al., 2002; Treude et al., 2003; Niemann et al., 2006b).

72 This process significantly affects seep habitats by inducing the precipitation of carbonate

73 (Ritger et al., 1987; Wallmann et al., 1997) and by producing sulfide, both of which

74 provide additional niches to a variety of microbial communities and benthic fauna,

75 including chemosynthetic microbe-animal symbioses, such as in siboglinid tubeworms, 
76 mytilids and vesicomyid bivalves (Sibuet and Olu-Le Roy, 2002). AOM is mediated by a

77 presumably syntrophic association between Methanosarcinales, Methanomicrobiales and

78 Methanococcoides related anaerobic methanotrophic archaea (ANME groups 1-3) and

79 sulfate-reducing bacteria (SRB) of the Desulfosarcina/Desulfococcus or the

80 Desulfobulbus clusters (Boetius et al., 2000a; Orphan et al., 2001; Knittel et al., 2005;

81 Niemann et al., 2006b; Lösekann et al., 2007). A distinct variety of other bacteria and

82 archaea have been repeatedly detected associated with ANME in cold seep systems,

83 however, their function remains unknown (Knittel et al., 2003; Knittel et al., 2005; Mills

84 et al., 2005).

85 The Eastern Mediterranean basin is known as one of the most oligotrophic areas

86 of the world's oceans. It is characterized by low particle flux rates, deep oxygen and

87 sulfate penetration into the seafloor, due to low rates of organic matter mineralization and

88 low microbial cell numbers (Boetius and Lochte, 1996). Hence, sulfidic environments at

89 the deep seafloor of the Eastern Mediterranean are typically associated with local

90 advection of electron donors from the deep subsurface, such as by fluid flow and gas

91 seepage. Active cold seep systems in the Eastern Mediterranean have been the subject of

92 several studies that have included mud volcanoes on the Eastern Mediterranean Ridge,

93 such as Napoli and Milano in the Olimipi area and Amsterdam and Kazan in the

94 Anaximander mountains (Aloisi et al., 2000; Pancost et al., 2000; Aloisi et al., 2002;

95 Charlou et al., 2003; Haese et al., 2003; Heijs, 2005; Mills et al., 2005; Bouloubassi et al.,

96 2006; Heijs et al., 2006). Highly ${ }^{13}$ C-depleted archaeal biomarkers (i.e. archaeol,

97 2,6,10,15,19-pentamethylicosane (PMI) and others), indicative of AOM, have been

98 recovered from carbonates and sediments at these seeps (Aloisi et al., 2000; Pancost et al., 
99 2000; Aloisi et al., 2002; Heijs, 2005; Bouloubassi et al., 2006; Heijs et al., 2006).

100 Evidence for SR coupled to AOM at these sites has been made primarily on the basis

101 of ${ }^{13} \mathrm{C}$-depleted bacterial lipids, believed to originate from methane dependent SRB

102 (Aloisi et al., 2000; Pancost et al., 2000; Aloisi et al., 2002; Heijs, 2005; Bouloubassi et

103 al., 2006; Heijs et al., 2006). Furthermore, 16S rRNA gene surveys of sediments from

104 these mud volcanoes have revealed the presence of different types of ANME (Heijs, 2005;

105 Heijs et al., 2005), i.e. ANME-1 and 2, as well as their sulfate reducing partners, which

106 are related to the Desulfosarcina/Desulfococcus cluster.

$107 \quad$ Here we present the first AOM and SR activity measurements, in relation to

108 microbial community structure, of cold seep systems of the NDSF. We focused on cold

109 seeps of the Eastern (Amon, Isis mud volcanoes), Central (North Alex mud volcano,

110 pockmark areas) and Western (Chefren mud volcano) NDSF, as well as on the Napoli

111 mud volcano of the Olimpi field on the Central Mediterranean Ridge. We used whole

112 core tracer injection methods to quantify rates of methane oxidation and sulfate reduction,

113 and 16S rDNA-based molecular tools to investigate the microbial community structure.

114 The questions addressed by this study were: (1) What is the range of microbial methane

115 and sulfate consumption at different types of seeps of the NDSF? (2) Which key

116 microorganisms mediate these processes?

\section{2. Regional settings}

119

A detailed description of the geology and evolution of fluid escape structures on

121 the NDSF has been published recently (Mascle et al., 2006; Dupré et al., 2007) and is 
122 provided in this volume by Huguen et al., (Huguen et al., In review, this volume). Fluid

123 escape structures and associated mud volcanoes are abundant on the Mediterranean Ridge

124 accretionary prism (Fusi and Kenyon, 1996; Huguen et al., 2004), and on the

125 Anaximander Mountains between the Hellenic and Cyprus arcs (Woodside et al., 1998;

126 Zitter et al., 2005). More recently, seepage activity was discovered on the NDSF

127 ((Loncke et al., 2004; Mascle et al., 2005; Mascle et al., 2006) and references therein).

128 Most of the NDSF was formed in the late Miocene and corresponds at present to the most

129 prominent sedimentary structure of the Eastern Mediterranean margin, with thick

130 sediment deposits of more than 9-10km. The fluid escape structures of the Eastern,

131 Central and Western province of the NDSF investigated here appear connected to salt

132 tectonics and subsequent gravitational forces causing a spreading and gliding of the thick

133 sedimentary packages on the NDSF. Furthermore, the Egyptian slope is a prolific domain

134 for hydrocarbons with its large subsurface gas and oil reservoirs (Dolson et al., 2002);

135 and these fuel many active fluid escape structures on the NDSF of which only few have

136 been investigated to date.

137 The mud volcanoes Amon and Isis of the Eastern NDSF, North Alex of the

138 Central NDSF (Dupré et al., 2007); and Chefren and Mykerinos of the Western NDSF

139 (Huguen et al., In review, this volume), were sampled for the first time with the

140 submersible Nautile (IFREMER) during the NAUTINIL expedition in 2003 (Fig. 1).

141 These mud volcanoes are circular features (1-3 km in diameter) in water depths of 500 -

$1423000 \mathrm{~m}$ with elevations of up to $100 \mathrm{~m}$ above the seabed (Dupré et al., 2007). They are

143 located above well-developed feeder channels, clearly seen in the seismic data (Loncke et

144 al., 2004; Dupré et al., 2007; Huguen et al., In review, this volume). In the deeper central 
145 province of the NDSF we sampled a field characterized by abundant pockmarks of 3-15

$146 \mathrm{~m}$ diameter between extensive flat carbonate pavements covering the seafloor (Bayon et

147 al., In review, this volume). For comparison, we also investigated a fluid escape structure

148 on the central Mediterranean Ridge, the Napoli mud volcano, which is located within the

149 Olimpi area (Camerlenghi et al., 1992; Huguen et al., 2005) (Fig. 1).

150

151 3. Material and Methods

152

153 At all sites, sediment samples were collected by blade (Width $\times$ Height $\times$

154 Length: $10 \times 25 \times 40 \mathrm{~cm}$ ) and push corers(Diameter $\times$ Length: $5 \times 25 \mathrm{~cm}$ ) by the submersible

155 Nautile. Generally, cores were retrieved on board less than 5 hours after coring.

156 Immediately upon returning to the RV L'Atalante, the cores were taken to the cold room,

157 sub-sampled and processed for the measurements outlined below. Table 1 list the cores

158 recovered from each site as well as their treatment.

1603.1 Methane concentration

161 Due to sampling constraints, methane concentration data from two different types

162 of initial processing methods were included within this study. The sediments were

163 sectioned horizontally ( $2 \mathrm{~cm}$ intervals, corresponding to $2 \mathrm{ml}$ of sediment) and placed in

$16418 \mathrm{ml}$ glass vials containing $10 \mathrm{ml}$ of $2.5 \% \mathrm{NaOH}$. The vials were immediately sealed

165 with rubber stoppers. Alternatively, sections were equilibrated with a saturated $\mathrm{NaCl}$

166 solution (ca. $300 \mathrm{~g} /$ ) in rubber sealed glass vials for at least 12 hours. The sediment

167 slurries were shaken, and $100 \mu \mathrm{l}$ of headspace removed by a glass syringe. Methane 
168 concentrations were measured by injecting $100 \mu \mathrm{l}$ of headspace in a Hewlett Packard

169 5890A or a Shimadzu GC-14B gas chromatograph. The detector for both chromatographs

170 was a flame ionization detector.

171

$172 \quad 3.2$ Methane oxidation

173 Methane oxidation rates were measured using dissolved ${ }^{14} \mathrm{CH}_{4}$, based on

174 previously described methods (Iversen and Blackburn, 1981; Treude et al., 2003). Pre-

175 drilled cores were used to sub-sample the push cores. The holes were spaced $1 \mathrm{~cm}$ apart

176 and sealed with silicone prior to sub-sampling. Immediately after sub-sampling, subcores

177 were sealed with a rubber stopper and placed in the dark at the in situ temperature of

$17814^{\circ} \mathrm{C}$ for $1-2$ hours. Ten microliters of ${ }^{14} \mathrm{CH}_{4}(\sim 0.25 \mathrm{kBq})$ were then injected through

179 the silicon plugs into the sediment, and the sub-cores were incubated in the dark at in situ

180 temperature for $24 \mathrm{hr}$. The cores were then quickly sectioned into $2 \mathrm{~cm}$ layers, and the

181 sections fixed in $10 \mathrm{ml}$ of $2.5 \% \mathrm{NaOH}$ as for methane concentration determinations.

182 Further processing was done according to Treude et al. (Treude et al., 2003). Rates were

183 calculated according to the equation below, where ${ }^{14} \mathrm{CO}_{2}=$ activity of $\mathrm{CO}_{2}$

184 produced, ${ }^{14} \mathrm{CH}_{4}=$ activity of residual tracer, $\mathrm{CH}_{4}=$ residual $\mathrm{CH}_{4}, V=$ sediment volume

185 and $t=$ incubation time.

186

$$
\text { AOM rate }=\left({ }^{14} \mathrm{CO}_{2} /\left({ }^{14} \mathrm{CO}_{2}+{ }^{14} \mathrm{CH}_{4}\right)\right) \times\left[\mathrm{CH}_{4}\right] / \mathrm{V} / \mathrm{t}
$$

\section{$188 \quad 3.3$ Sulfate concentration}

189 As with methane concentration measurements, two separate methods were used to

190 initially process and measure sulfate concentrations. Subcores were sectioned 
191 horizontally (2 cm intervals, corresponding to $2 \mathrm{ml}$ of sediment) and sections were placed

192 in $15 \mathrm{ml}$ polypropylene vials with $5 \mathrm{ml}$ of $20 \%$ zinc acetate and shaken thoroughly. The

193 sediment slurry was then centrifuged at $5000 \mathrm{rpm}$ for five minutes and the supernatants

194 removed and transferred to clean polypropylene vials. The supernatants were analyzed

195 using non-suppressed ion chromatography with an anion exchange column (LCA A14,

196 Sykam) and a conductivity detector (S3110, Sykam). Alternatively, pore water was

197 squeezed from the sediment sections and sulfate measured as S using inductively coupled

198 plasma atomic emission spectroscopy (ICP-AES).

199

200 3.4. Sulfate reduction

201 Sulfate reduction rates were measured by ${ }^{35} \mathrm{SO}_{4}{ }^{-2}$ whole core injection incubations

202 (Treude et al., 2003). Parallel to the methane oxidation samples, sediment subcores were

203 pre-incubated, injected with $5 \mu \mathrm{l}$ of ${ }^{35} \mathrm{SO}_{4}{ }^{-2}(10 \mathrm{kBq})$ and incubated for 24 hours at in situ

204 temperature before fixation in $5 \mathrm{ml}$ of $20 \%$ zinc acetate. The samples were then

205 processed according the method described by Kallmeyer et al. (Kallmeyer et al., 2004).

206 Rates were calculated according to the equation below, where $\operatorname{TRI}^{35} \mathrm{~S}=$ activity of total

207 reduced inorganic sulfur, ${ }^{35} \mathrm{SO} 4=$ activity of residual tracer, $\mathrm{SO}_{4}{ }^{-2}=$ residual $\mathrm{SO}_{4}{ }^{-2}$

208 within the sample, $V=$ sediment volume, and $t=$ time.

$209 \quad$ SR rate $=\left(\mathrm{TRI}^{35} \mathrm{~S} /\left(\mathrm{TRI}^{35} \mathrm{~S}+{ }^{35} \mathrm{SO}_{4}{ }^{-2}\right)\right) \times\left[\mathrm{SO}_{4}{ }^{-2}\right] / \mathrm{V} / \mathrm{t}$

2113.5 Acridine Orange Direct Counts (AODC) and Fluorescence In Situ Hybridization

212 (FISH)

213 Two milliliters of sediment were placed in a $20 \mathrm{ml}$ plastic tube with $9 \mathrm{ml}$ of a $2 \%$

214 formalin and artificial seawater solution for $4 \mathrm{hr}$ at room temperature. At the end of the 
215 incubation period, half of the mixture was washed twice in PBS and stored in a

216 PBS $\backslash$ ethanol solution (50:50) at $-20^{\circ} \mathrm{C}$ for FISH, the other half was stored at $4^{\circ} \mathrm{C}$ for

217 AODC. AODC (Boetius and Lochte, 1996), FISH (Snaidr et al., 1997) and CARD-FISH

218 (Pernthaler et al., 2002; Ishii et al., 2004) were all performed according to previously

219 described methods. All FISH and CARD-FISH slides were counter-stained with DAPI

220 (4',6'- diamidino-2-phenylindole). At least 30 - 50 grids were counted randomly from

221 each slide for AODC, FISH and CARD-FISH. Probe hybridization details are given in

222 Table 2. No signal was observed using the ANME-2, and M $\gamma 705$ CARD-FISH probes,

223 therefore ANME-2 and My705 targeted cells were enumerated using monolabeled FISH

224 probes. Cell numbers within conspicuous ANME-SRB aggregates were estimated using a

225 semi-direct method (Boetius et al., 2000b). All aggregates and cells were assumed to be

226 spherical. The average cell volume was estimated to be $0.065 \mu^{3}$. The volume of an

227 average aggregate $\left(82 \mu \mathrm{m}^{3}\right)$ was determined by randomly measuring the diameter of 50

228 aggregates on filters from Amon (NL12PC2) and Chefren (NL18PC2(7)). The average

229 aggregate volume was divided by the average cell volume, and a ratio of 1:1 archaeal to

230 bacterial cells was used to calculate the number of bacterial and archaeal cells per

231 aggregate.

232

233 3.6 16S rDNA library construction and analysis

234 Sediments were sectioned into $2 \mathrm{~cm}$ intervals and frozen at $-20^{\circ} \mathrm{C}$ until further

235 processing. 16S rDNA libraries for Archaea and Bacteria were created after Niemann et

236 al. (Niemann et al., 2006a). Briefly, total DNA was extracted from the first $4 \mathrm{~cm}$ of

237 sediment ( $0.3 \mathrm{~g})$ with the FastDNA spin kit for soil, essentially following the 
238 manufacture’s recommendations (Q-Biogene, Irvine, California, USA). Partial 16S genes

239 were amplified using the primers ARCH20F (Massana et al., 1997) and Uni1392R (Lane

240 et al., 1985) for Archaea and GM3F (Muyzer et al., 1995) and GM4R (Kane et al., 1993)

241 for Bacteria. Amplification products were then cloned and sequenced in one direction on

242 an ABI 3100 genetic analyzer. Single directional reads were then added to preexisting

243 phylogenetic trees using the parsimony tool in the ARB software package (Ludwig et al.,

244 2004) to determine their phylogenetic affiliations. P-tests were conducted for

245 comparisons between sequence libraries in this study using the program S-LIBSHUFF

246 version 1.22 (Schloss et al., 2004). Distance matrices were created in ARB (Ludwig et

247 al., 2004) using the Neighbor-joining tool. Sequences were submitted to the GenBank

248 database (http://www.ncbi.nlm.nih.gov/) and are accessible under the following accession

249 numbers: EF687258-EF687340, EF687432-EF687519, EF687520-EF687656 and

250 EU178928-EU179209

251

2524 Results and Discussion

253 Previous to this investigation, the activity at cold seeps within the NDSF with

254 regard to fluid escape, hydrocarbon oxidation, sulfide production and the composition of

255 seep-associated benthic microbial communities was unknown. A variety of fluid escape

256 structures, including mud volcanoes, brine seeps and pockmarks were visited in

257 September 2003 by the expedition NAUTINIL. Most strikingly, almost all structures

258 showed signs of active gas seepage, fluid flow, mud volcanism and authigenic carbonate

259 formation (Dupré et al., 2007; Bayon et al., In review, this volume; Huguen et al., In

260 review, this volume). Hence, the abundances of cold seeps, sites of hydrocarbon 
261 emission, chemosynthetic communities and anoxic microbial ecosystems in the highly

262 oligotrophic Eastern Mediterranean are much greater than previously considered.

\section{$264 \quad 4.1$ Eastern province of the NDSF}

\subsubsection{Dive observations}

267 Five dives were dedicated to investigating the methane turnover and microbiology 268 of active sites of the Amon and Isis mud volcanoes (Figs. 1A,B and Table 1). For detailed 269 geological and morphological descriptions of Amon and Isis see Dupre et al. (Dupré et al.,

270 2007; Bayon et al., Submitted). Visual observations of both mud volcanoes provided

271 evidence for active seepage and methane consumption at their centers. We observed areas

272 of highly disturbed seafloor, with fresh cracks, troughs and grayish mud breccia. Blackish,

273 reduced sediment patches of 0.5 - $4 \mathrm{~m}$ in diameter were also observed around the freshly

274 disturbed areas. These were frequently covered with mats of sulfide-oxidizing bacteria

275 (Fig. 2A,B). Our sampling efforts concentrated on those sites, as the presence of sulfide-

276 oxidizing bacterial mats point to active subsurface processes producing and transporting

277 sulfide to the seafloor (Treude et al., 2003; Niemann et al., 2006b; Bayon et al., In review, 278 this volume).

279 Two sediment push cores were recovered from black sediment patches in the 280 center of Amon (Table 1, Fig. 2A: NL11PC1, NL12PC2) and three pushcores from such

281 microhabitats in the center of Isis (Table 1, Fig. 2B: NL8PC1(4), NL18PC3(1) and

282 NL13PC4(7)). Sporadic gas ebullition from the seafloor was observed at Amon and Isis

283 upon sampling and submersible touch-down in the center of these mud volcanoes. The 
284 sedimentology of all push cores from the active centers of both mud volcanoes was

285 consistent with our visual observations in pointing towards active mud volcanism and

286 advective transport of hydrocarbons (Fig. 3A,B). The surfaces of both cores from Amon

287 were covered with sulfide-oxidizing bacterial mats above reduced sediments followed by

288 lighter grayish mud breccia below (Fig. 3a). All three cores recovered from Isis (Fig. 3B)

289 contained dark grey mud breccia and two cores had small whitish aggregates at the

290 surface indicating the presence of sulfide-oxidizing bacteria (NL8PC1(4), NL8PC3(1)).

291 The local variation in terms of topography and sedimentology at both mud volcanoes is

292 not surprising, given that fluid and gas flow at most cold seeps is focused, which can

293 result in large sediment heterogeneities (Sahling et al., 2002; Luff and Wallmann, 2003).

295 4.1.2 Sulfate reduction and anaerobic oxidation of methane

296 Large gas plumes with high concentrations of methane have been detected above

297 the centers of Amon and Isis ( 0.5 and $0.7 \mu \mathrm{M}$, respectively), indicating recent gas

298 ebullition at both mud volcanoes (Dupré et al., 2007). When retrieved to deck, all cores

299 from the center of Isis and Amon had cracks within the sediment indicating gas escape

300 during recovery. Accordingly, methane concentrations measured in all recovered

301 sediment cores from both mud volcanoes centers exceeded $1 \mathrm{mM}$ (Fig. 3A,B), and some

302 cores still contained gas bubbles during sub-sampling. Despite high methane

303 concentrations, sulfate concentrations exceeded $5 \mathrm{mM}$ throughout the cores, with

304 moderate anaerobic oxidation of methane (AOM) rates $\left(0.1-3.7\right.$ mmoles $\left.\mathrm{x} \mathrm{m}^{-2} \mathrm{x} \mathrm{d}^{-1}\right)$.

305 Sulfate reduction (SR) rates (0.7 - 24 mmoles $\left.\mathrm{x} \mathrm{m}^{-2} \mathrm{x} \mathrm{d}^{-1}\right)$ were much higher (Table 3).

306 The peaks in SR coincided with reduced sediment layers stained black by FeS 
307 precipitation in the cores from Amon (Fig. 3A) and one from Isis (NL8PC1(4)). In two

308 cores from Isis (NL8PC3(1)) and (NL13PC4(7)), SR activity was distributed evenly

309 throughout the cores but blackish sediment layers were not observed. SR activity

310 exceeded that of AOM by several fold and may have been supported by other electron

311 donors, transported together with methane. $C_{2}$ and higher hydrocarbons have been

312 detected in sediments and bottom waters of Amon and Isis (Dupré et al., 2007). A

313 decoupling of AOM and SR in the presence of higher hydrocarbons has already been

314 observed in seep sediments of the Gulf of Mexico (Joye et al., 2004) and the Gulf of

315 Cadiz (Niemann et al., 2006a). Sulfate reducers are capable of using a wide variety of

316 hydrocarbons as electron donors; hence it is likely that the availability of higher

317 hydrocarbons selects for other sulfate reducers besides the ANME partner SRB, as the

318 energy yield from AOM is very low (Widdel and Rabus, 2001; Widdel et al., 2006/2007;

319 Kniemeyer et al., 2007).

320

321 4.1.3 Microbial community structure

322 Total cell numbers were $10^{8}-10^{9}$ cells $\mathrm{x} \mathrm{ml}{ }^{-1}$ in surface sediments of both mud

323 volcanoes (Table 4), which is the lower end of numbers observed at other active seep

324 settings $\left(>10^{10}\right.$ cells $x \mathrm{ml}^{-1}$ ) (Michaelis et al., 2002; Knittel et al., 2003; Tina Lösekann et

325 al., 2007). Fluorescence in situ hybridization (FISH) (Tables 4) and 16S rRNA gene

326 analysis (Table 5) were carried out on two selected cores from Amon (NL12PC1) and Isis

327 (NL13PC4(7)), both covered by bacterial mats. These cores were selected on the basis of

328 rates, methane and sulfate concentrations, and visual characteristics indicating seepage

329 related microbial activity. The dominance (36 - 58 \%) of Deltaproteobacteria sequences 
330 in the 16S rRNA gene library for Bacteria of both mud volcanoes were in accordance

331 with the relatively high, near surface SR rates. A large portion of the 16S rDNA

332 sequences were related to SRB of the genera Desulfosarcina, Desulfococcus,

333 Desulfocapsa and Desulfobulbus, which are ubiquitous at seeps and have been previously

334 implicated as partners of methanotrophic archaea (ANME) (Knittel et al., 2003). The

335 probe DSS658, which targets the Desulfosarcina/Desulfococcus cluster, showed that

336 most of these cells were aggregated with ANME-2 cells at Amon, whereas at Isis most of

337 the DSS658 targeted cells were single cells. Compared to their high percentage in the

338 bacterial 16S rRNA gene library (19\%; Tab. 4), DSS658 targeted cells made up only 2-

$3393 \%$ of the overall cell numbers at Isis, but up to $50 \%$ at Amon. Interestingly, the core

340 NL12PC1 from Amon also showed considerably closer coupling of AOM to SR. The

341 dominance of the Archaea libraries by sequences most closely related to ANME-2, and

342 their relatively high cell numbers was matched by relatively high AOM rates. ANME-1

343 and -3 cells were also detected, but their numbers were below $1 \%$ of the total cells.

344 Several sequences belonging to methanogens of the genus Methanococcoides were

345 detected in sediments of both mud volcanoes. Incubations with these sediments under

346 methanogenic conditions with methanol produced substantial enrichments of

347 Methanococcoides (T. Holler, unpublished data), indicating that these organisms were

348 viable. These archaea are capable of growing on C-1 compounds and could contribute to

349 local methane concentrations, however, their source of energy in the investigated

350 sediments remains unknown. Also several other typical groups of cold-seep associated

351 Archaea and Bacteria were detected (e.g. Marine Benthic Group 1(MBG1), Benthic

352 Group D (MBGD), and members of the Gammaproteobacteria); but the metabolic 
353 function and environmental role of these organisms was not further investigated here.

354 Interestingly, at both mud volcanoes a significant portion of the Bacteria (EUB) cells in

355 consortium with ANME cells were not targeted by DSS658 or 660, indicating that other

356 bacterial partners were present and potentially involved in AOM. This was previously

357 also observed at other sites such as the Eel River Basin (Pernthaler et al., 2008).

358 Statistical tests (P value $<5 \%$ ) indicated that the 16S rRNA gene library of

359 Archaea at Amon was different from that at Isis. However, the reciprocal comparison

360 (Isis to Amon) indicated no statistical difference ( $\mathrm{P}$ value $>5 \%$ ) between them,

361 suggesting that both environments shared a subset of Archaea. This was also true for

362 comparisons of the $16 S$ rRNA gene libraries of Bacteria, which indicated that the

363 communities at both mud volcanoes were not significantly different from one another.

364 The similarities between the microbial communities of both mud volcanoes are not

365 surprising given their very similar geochemistry.

366

367 4.2 Central province of the NDSF

368

369 4.2.1 Dive observations

370 Three dives were dedicated to investigating different seafloor structures of the

371 central province (Fig.1A, C): The active center of the North Alex mud volcano, and a

372 region characterized by pockmarks and vast areas of carbonate crusts. For detailed

373 morphological and geological descriptions of North Alex and the pockmarks see Dupre et

374 al. (Dupré et al., 2007) and Bayon et al. (Bayon et al., In review, this volume). The

375 central NDSF is comprised of three domains: an upper, middle and lower slope. The 
376 upper slope hosts large gas chimneys associated with mud volcanoes such as North Alex.

377 The seafloor of the center of North Alex was much less disturbed than that of Amon and

378 Isis, and was essentially flat. However, the center sediments were overpressurized with

379 gas, as evidenced from spontaneous gas ebullition observed during the dive (Fig. 4A).

380 The single blade core recovered from the center was gas saturated and contained mud

381 breccia interspersed with small chunks of carbonate (Figure 5A). Bacterial mats were not 382 observed in the center of North Alex.

383 The middle slope area was characterized by a flat seafloor covered by vast areas

384 of carbonate pavement (> $1 \mathrm{~km}$ ) associated with empty shells and tubes, and relatively

385 sparse patches of living chemosynthetic fauna, interspersed by reduced, grayish

386 sediments, as well as many pockmarks (Fig. 4B). The pockmarks were circular

387 depressions of approximately 3-15 $\mathrm{m}$ in diameter and up to $3 \mathrm{~m}$ depth below the

388 surrounding seafloor. Carbonate crusts and chemosynthetic fauna (Fig. 4B) were

389 observed in the central depressions of the pockmarks, indicating a connection between

390 gas flow, microbial methane oxidation and carbonate precipitation (Bayon et al., In

391 review, this volume). One core was taken within a small pockmark (NL6PC1), and

392 another one (NL7PC1) from pelagic sediments of light brown color just outside of a

393 carbonate-covered area.

$394 \quad$ The area on the lower slope also showed extensive $(\sim 500 \mathrm{~m})$ flat and partially

395 broken carbonate crusts, which hosted seep-associated fauna and lots of shell debris. The

396 larger carbonate pavements on the middle and lower slope were interspersed by reduced

397 blackish sediments (Fig. 4C), littered by shell debris. They hosted a variety of small

398 chemosynthetic bivalves as well as small patches of living siboglinid tube worms (Fig. 
399 4D). These organisms likely depended on the sulfide flux derived from hydrocarbon-

400 fueled sulfate reduction in sediments below the crust. Outside the flat area, many small

401 carbonate mounds and small $(<3 \mathrm{~m})$ pockmarks were observed. Here, one core was taken

402 close to a small carbonate mound (NL14PC2). In contrast to Amon, Isis and North Alex,

403 the pockmarks appeared to be an area of reduced but probably long-term seepage activity

404 as discussed by Bayon et al. (Bayon et al., In review, this volume).

405

406 4.2.2 Sulfate reduction and anaerobic oxidation of methane

$407 \quad$ Methane concentrations of up to $0.2 \mu \mathrm{M}$ in the bottom water above the centre of

408 North Alex indicated that this mud volcano actively emitted methane, similar to Amon

409 and Isis (Dupré et al., 2007). According to the visual observations, the sediments were

410 gas-saturated at the seafloor. Methane concentrations in retrieved cores from North Alex

411 were up to $1.8 \mathrm{mM}$. In contrast, the bottom waters of the middle and lower slope areas

412 next to the pockmarks and carbonate pavements showed no or very low methane

413 anomalies (Bayon et al., In review, this volume). Correspondingly, sediment cores from

414 these areas contained less than $10 \mu \mathrm{M}$ methane.

$415 \quad$ SR and AOM rates measured (Fig. 5A and Table 3) at North Alex were 4 and 3.4

416 mmol x m $\mathrm{x} \mathrm{d}^{-1}$ within the top $10 \mathrm{~cm}$, respectively, indicating a tight coupling ( 1.2:1)

417 between SR and AOM. Sulfate and methane were not completely depleted within this

418 zone, indicating that neither electron donor nor acceptor was limiting the ANME

419 community, and that advective transport methane from below was probably high. In

420 contrast, SR and AOM rates were generally $<0.1 \mathrm{mmol} \mathrm{m}^{-2} \mathrm{~d}^{-1}$ (integrated over the first

$421 \quad 10 \mathrm{~cm})$ at the middle slope in samples taken next to a carbonate mound within a 
422 pockmark, as well as outside the pockmark and carbonate areas. Only the core from dive

423 NL14 taken next to the carbonate mound (lower slope) showed higher rates (2.8 mmol x

$424 \mathrm{~m}^{-2} \mathrm{x} \mathrm{d}^{-1}$ ). However, here, maximum rates were found below $10 \mathrm{~cm}$ sediment depth. This

425 is consistent with observations made by Bayon et al. (Bayon et al., In review, this

426 volume), which suggested that the sediments beneath the crusts are active in methane

427 turnover.

428

429 4.2.3 Microbial community structure

430 We chose the most active samples for analysis of the distribution of different

431 microbial groups; the core from the center of North Alex (NL15BC1) and the core next to

432 a small carbonate mound on the lower slope (NL14PC2). Cell numbers at North Alex

433 were $>10^{9} \times$ cells $\times \mathrm{ml}^{-1}$ in the surface sediments, but only a few consortia were detected

434 (Table 4). Interestingly, ANME-1 and -2 cells comprised only a small part of the archaeal

435 cells that were detected in both sediments. Furthermore, bacterial cells within the

436 aggregates were not targeted by DSS658, indicating that unknown bacterial partners were

437 involved in the AOM consortia. The vast majority of cells in the sediments were

438 unknown single cell Bacteria; only $6 \%$ of these were targeted by DSS658. The cell

439 numbers from the pockmark region (NL14(PC2)) were considerably lower (0.4 - $0.910^{9}$

$440 \times$ cells $\times \mathrm{ml}^{-1}$ ) and methane-oxidizing archaea were virtually absent from these sediments.

441 However, microbial biomarker analysis of carbonates from this site indicated that

442 ANME-2 were the dominant group within the carbonates (Gontharet, unpublished data,

443 Stadnitskaia unpublished data), which suggests that AOM was of greater importance in 
444 the past. Unfortunately, the active sediments below these carbonates could not be

445 sampled.

446

447 3.3 Brine-influenced gas seeps: Western Province of the NDSF and the Olimpi mud

448 volcano field

449

$450 \quad$ 3.3.1 Dive observations

451 Three dives were dedicated to investigating sites of hydrocarbon and brine

452 seepage in the Western Province of the NSDF and the Olimpi field of the Central

453 Mediterranean Ridge (Table 1). The Chefren mud volcano is located within the Menes

454 caldera in the Western Province ((Huguen et al., In review, this volume); Fig. 1A,E). The

455 center of this mud volcano hosts a large submarine lake of approximately 200m diameter

456 filled with fluidized mud and brines which were partially covered by mats of sulfide

457 oxidizers and their precipitates (Fig. 6A). The edges of the central lake were covered by

458 clear brines (Fig. 6B). In contrast, the center of the Napoli mud volcano had many

459 smaller sized brine pools of several meters to tens of meters, some of which were drained

460 (Fig. 4C). This area was previously investigated and further details of its geological,

461 geochemical and biological characteristics have been published elsewhere (Charlou et al.,

462 2003; Olu-Le Roy et al., 2004; Haese et al., 2006). We recovered 5 samples from the

463 slope (NL4PC1, NL18PC2(7) and PC4(6)) and center of Chefren (NL19PC1(5) and

464 PC3(8)), as well as 4 cores from the center of Napoli (NL1PC2, NL21PC5(1) and PC6(2),

465 NL22PC7(3)) (Table 1). All cores recovered from these seafloor areas were covered by 
466 visible bacterial mats and their mineral precipitates, which varied considerably in color

467 and composition.

$468 \quad$ At a mud cone on the NW flank of Chefren, colorful white and orange microbial 469 mats were associated with brine seepage (Fig. 6D). These mats have been described in 470 detail elsewhere (Omoregie et al., 2008). Briefly, the orange mats comprised sheaths of

471 iron-oxidizing Bacteria as well as iron-oxide precipitates. The white mats comprised 472 mainly sulfur filaments, produced by “Candidatus Arcobacter sulfidicus”. Two cores 473 (NL4PC1 and NL18PC4(6)) were retrieved from the sulfide-oxidizing mats and one core 474 from iron-oxidizing mats (NL18PC2(7)) at the bottom of the north-western slope of 475 Chefren (Tab. 1). Brine was observed flowing over the sulfide-oxidizing mats (Omoregie 476 et al., 2008) and cores from these mats showed a highly reduced, blackish sediment 477 horizon directly below the surface, followed by dark grey mud breccia (Fig. 7A). In 478 contrast, the core from the iron-oxidizing mat (Fig. 7B) had a reduced layer in the middle 479 of the core, which was surrounded by brownish sediment. The two cores from the center 480 of Chefren were taken directly from the edge of a large brine lake in an area covered by 481 clear brine (NL19PC1(5), PC3(8)). A thin line of bacterial mats formed directly between 482 the interface of the brine and the seafloor (Fig. 6B). Both cores had reduced layers at the 483 surface followed by dark brown sediment.

484 In the center of Napoli abundant patches of white bacterial mats (Fig. 6E) as well 485 as extensive carbonate crusts were visible at the seafloor (Fig. 6F). These carbonate 486 crusts were also frequently perforated with tube worms similar to the pockmark area of 487 the Central NDSF. Two cores from thin sulfide-oxidizing mats (NL1PC2M and 488 NL22PC3) and two cores from exposed blackish sediment between crusts (NL21PC1 and 
2) were recovered from Napoli. All cores showed reduced sediment layers at the surface

490 and dark grey sediment, interspersed with carbonate.

491

492 3.3.2 Sulfate reduction and anaerobic oxidation of methane

493 Methane concentrations in the bottom waters above the center of Chefren were

494 relatively high $(40 \mu \mathrm{M})$. In contrast those at Napoli were relatively low (20 nM)

495 Mastalerz et al. unpublished data). The brines from both Chefren and Napoli (salinity of

496 up to 153 and $268 \%$ o, respectively) contained high amounts of methane (up to 0.7 and

$4972.5 \mathrm{mM}$ ) and sulfide (up to 7.1 and $2.1 \mathrm{mM}$ ), but also sulfate (5-57 mM) (Huguen et al.,

498 In review, this volume). The sediments sampled from Chefren contained similar amounts

499 of methane as found at the other seeps of the NDSF (0.2 - $2 \mathrm{mM}$ ). At Napoli, methane

500 concentrations in the sediments were low (0.04-0.08 mM). The samples recovered from

501 the Chefren and Napoli MV showed a wide range of SR and AOM rates (0.2 - 66.5 and

$\left.5020.1-2.3 \mathrm{mmol} \mathrm{cm}^{-2} \mathrm{~d}^{-1}, 0-10 \mathrm{~cm}\right)$. At both sites, SR exceeded AOM considerably,

503 pointing to the presence of hydrocarbon sources other than methane (Fig. 7A-C and Table

504 3). The highest rates were generally located close to the surface, similar to the other cores

505 investigated in this study. Sulfate concentrations remained very high throughout the cores,

506 even close to the peaks of SR, possibly indicating advective transport by brine seepage

507 (Fig. 7).

508

509 3.3.4 Microbial community structure

510 Similar to the 16S rRNA gene libraries of Amon and Isis, those from the slope of

511 Chefren were dominated by sequences from the Deltaproteobacteria and ANME-2 or 
512 ANME-3 (Table 5). Also, sequences of aerobic methanotrophs were abundant in samples

513 of mat and surface sediments. Total cell numbers in mat-covered sediments from the

514 slope of Chefren were slightly lower than those from the center of Amon and Isis (Table

515 4). ANME-2 and -3 cells only made up a small proportion of total archaeal cells,

516 indicating that other archaeal groups, such as MBGD may represent a significant biomass

517 in these sediment zones. In contrast, a relatively high proportion of the bacterial cells

518 were identified as sulfate reducers targeted by the DSS658 probe.

519 The cell numbers in surface sediments recovered from Napoli of around $2 \times 10^{10}$

520 cells $\times \mathrm{ml}^{-1}$ were very high, but decreased within a few $\mathrm{cm}$ below the surface to numbers

521 similar to the other mud volcanoes in this study. The composition of Archaea at Napoli

522 was different from other cold seeps in the NDSF. ANME-1 cells appeared to be the

523 dominant ANME in the core from Napoli and ANME-2 were absent. Very few consortia

524 were detected in the Napoli sediments. Bacteria of the Desulfosarcina/Desulfococcus

525 cluster were abundant as free-living cells. This matched previous work conducted on

526 sediments and carbonates recovered from Napoli (Pancost et al., 2000; Aloisi et al., 2002;

527 Heijs, 2005). These studies detected highly ${ }^{13} \mathrm{C}$-depleted biomarkers of Archaea and SRB,

528 as well as 16S rRNA gene sequences from Napoli sediments, which were representative

529 for ANME-1 and DSS groups.

530 Comparisons between the bacterial libraries of sediments underlying the sulfide-

531 and iron-oxidizing mats at Chefren indicated that they were significantly different ( $\mathrm{P}$

532 value $<1 \%$ ). Despite the proximity of the cores ( $<2 \mathrm{~m}$ distance), the difference in

533 microbial community structure was not surprising given the markedly different

534 geochemistry between these two mats, especially with regard to dissolved iron and 
535 sulfide in the pore-waters (Omoregie et al., 2008).Comparisons of the archaeal and

536 bacterial 16S rRNA gene libraries between the brine impacted mud volcano Chefren, to

537 those of Amon and Isis indicated that they were significantly different ( $\mathrm{P}$ value $<1 \%$ ).

538 This suggests that the presence of brine may affect bacterial and archaeal community

539 structure, but not necessarily their function, e.g. sulfate reduction. This phenomenon has

540 already been observed in hypersaline photosynthetic communities (Clavero et al., 2000;

541 Nubel et al., 2000).

\section{4. Summary}

$544 \quad$ Here, we have provided AOM and SR measurements from cold seeps in the

545 Eastern Mediterranean. We show that the geology, chemistry and biology of these seep

546 environments are considerably influenced by microbial processes as indicated in previous

547 studies; hydrocarbon-driven sulfate reduction leads to the formation of anoxic microbial

548 habitats, carbonate precipitates and bacterial mats, all of which provide habitats for

549 associated fauna.

$550 \quad$ Only some of the investigated sediments showed a relatively tight coupling

551 between AOM and sulfate reduction (e.g. North Alex, Amon), indicated that at most sites

552 compounds other than methane were fueling sulfate reduction. At the active centres of the

553 Amon, Isis, North Alex, Chefren and Napoli mud volcanoes SR and AOM rates of 1-10

554 mmol x m${ }^{-2} \mathrm{x} \mathrm{d}^{-1}$ were measured. These rates are lower than at other known seep systems,

555 such as Hydrate Ridge (NE Pacific) and the Bush Hill site (Gulf of Mexico) with AOM

556 and SR rates of $50-100 \mathrm{mmol} \mathrm{m} \mathrm{d}^{-1}$ in sediments associated with bacterial mats

557 (Treude et al., 2003; Joye et al., 2004). The range of SR and AOM rates of the E. 
558 Mediterranean mud volcanoes matches seeps either limited by electron donor flux such as

559 at mud volcanoes in the Gulf of Cadiz (Niemann et al., 2006a), or by electron acceptor

560 depletion as at the Haakon Mosby mud volcano on the Norwegian margin (Niemann et

561 al., 2006b). In this study, sites with less than $100 \mu \mathrm{M}$ methane in the surface sediments

562 had very low AOM rates, hence methane availability may have been one factor in

563 controlling the AOM rates. But even at sites with high availability of methane, rates

564 were comparatively low. We did not reach the sulfate-methane transition zone in most of

565 the cores and sulfate concentrations were always above $5 \mathrm{mM}$ within the top $20 \mathrm{~cm}$ of

566 sediment. The relatively low SR and AOM rates at the investigated sites matched the

567 relatively low biomass of AOM consortia. An unknown factor other than energy supply

568 must control the standing stock of these key microorganisms at the cold seeps of the

569 Eastern Mediterranean, causing a low efficiency of the microbial filter eliminating the

570 methane flux to the ocean. Accordingly, strong methane anomalies were observed in the

571 water columns of all mud volcanoes investigated in this study.

572 To better understand the control of microbial activity, the sulfate and methane

573 flux, further studies are needed to reveal the diversity and quantities of electron donors

574 available to the microbial communities. Furthermore, due to the high heterogeneity and

575 local variation in advective flow at the mud volcano and pockmark sites, spatial sampling

576 needs to be improved, and in situ biogeochemical measurements are needed for

577 quantitative rate assessments.

578 


\section{Acknowledgements}

580 We would like to thank the crew and captain of RV L'Atalante, the NAUTILE crew as

581 well as the NAUTINIL scientific party for their excellent support with work at sea. Also

582 we thank Viola Beier, Imke Busse, Tomas Wilkop, Afua Asante-Poku and Abena

583 Asante-Poku for help with analyses, Katrin Knittel and Alban Ramette for scientific

584 advice, and Andrew Bisset for helpful comments on this manuscript. The work of E.O.,

585 H.N., and A.B. in the ESF EUROCORES EUROMARGIN project MEDIFLUX was

586 financially supported by ESF, DFG and the Max Planck Society.

587 


\section{References}

589 Aloisi, G. et al., 2002. CH4-consuming microorganisms and the formation of carbonate crusts at cold seeps. Earth and Planetary Science Letters, 203(1): 195-203.

591 Aloisi, G. et al., 2000. Methane-related authigenic carbonates of eastern Mediterranean

592 Sea mud volcanoes and their possible relation to gas hydrate destabilisation. Earth $593 \quad$ and Planetary Science Letters, 184(1): 321-338.

594 Bayon, G. et al., In review, this volume. In situ investigation of the Centre Nile margin:

595 Linking fluid seepage and continental-slope instabilities Marine Geology.

596 Bayon, G. et al., Submitted. In situ investigation of the Centre Nile margin: Linking fluid 597 seepage and continental-slope instabilities Marine Geology.

598 Boetius, A., Ferdelman, T. and Lochte, K., 2000a. Bacterial activity in sediments of the 599 deep Arabian Sea in relation to vertical flux. Deep Sea Res., 47: 2835-2875.

600 Boetius, A. and Lochte, K., 1996. Effect of organic enrichments on hydrolytic potentials 601 and growth of bacteria in deep-sea sediments. Mar. Ecol. Prog. Ser., 140: 239-250.

602 Boetius, A. et al., 2000b. A marine microbial consortium apparently mediating anaerobic 603 oxidation of methane. Nature, 407: 623-626.

604 Bouloubassi, I. et al., 2006. Archaeal and bacterial lipids in authigenic carbonate crusts 605 from eastern Mediterranean mud volcanoes. Organic Geochemistry, 37(4): 484606500.

607 Camerlenghi, A., Cita, M.B., Hieke, W. and Ricchiuto, T., 1992. Geological Evidence for 608 Mud Diapirism on the Mediterranean Ridge Accretionary Complex. Earth and 609 Planetary Science Letters, 109(3-4): 493-504. 
610 Charlou, J.L. et al., 2003. Evidence of methane venting and geochemistry of brines on 611 mud volcanoes of the eastern Mediterranean Sea. Deep-Sea Research Part I

612 Oceanographic Research Papers, 50(8): 941-958.

613 Clavero, E., Hernandez-Marine, M., Grimalt, J.O. and Garcia-Pichel, F., 2000. Salinity

614 tolerance of diatoms from thalassic hypersaline environments. Journal of

615 Phycology, 36(6): 1021-1034.

616 Coleman, D.F. and Ballard, R.D., 2001. A highly concentrated region of cold

617 hydrocarbon seeps in the southeastern Mediterranean Sea. Geo-Marine Letters, 618 21(3): 162-167.

619 Dolson, J.C., Boucher, P.J., Dodd, T. and Ismail, J., 2002. Petroleum potential of an 620 emerging giant gas province, Nile Delta and Mediterranean Sea off Egypt. Oil \& $621 \quad$ Gas Journal, 100(20): 32-37.

622 Dupré, S. et al., 2007. Seafloor geological studies above active gas chimneys off Egypt 623 (Central Nile Deep Sea Fan). Deep-Sea Research Part I: Oceanographic Research $624 \quad$ Papers, 54(7): 1146-1172.

625 Fusi, N. and Kenyon, N.H., 1996. Distribution of mud diapirism and other geological 626 structures from long-range sidescan sonar (GLORIA) data, in the Eastern

628 Haese, R.R., Hensen, C. and de Lange, G.J., 2006. Pore water geochemistry of eastern Mediterranean mud volcanoes: Implications for fluid transport and fluid origin.

631 Haese, R.R., Meile, C., Van Cappellen, P. and De Lange, G.J., 2003. Carbon geochemistry of cold seeps: Methane fluxes and transformation in sediments from 

Letters, 212(3-4): 361-375.

635 Heijs, S., 2005. Microbial communiteis at deep-sea mud volcanoes in the Eastern 636 Mediterranean Sea. PhD dissertation.

637 Heijs, S.K. et al., 2006. Microbial community structure in three deep-sea carbonate crusts. 638 Microbial Ecology, 52(3): 451-462.

639 Heijs, S.K., Damste, J.S.S. and Forney, L.J., 2005. Characterization of a deep-sea 640 microbial mat from an active cold seep at the Milano mud volcano in the Eastern 641 Mediterranean Sea. Fems Microbiology Ecology, 54(1): 47-56.

642 Hinrichs, K.-U. and Boetius, A., 2002. The anaerobic oxidation of methane: new insights 643 in microbial ecology and biogeochemistry. In: G. Wefer et al. (Editors), Ocean 644 Margin Systems. Springer-Verlag, Berlin, pp. 457-477.

645 Huguen, C. et al., In review, this volume. The Western Nile Margin Fluid seepages 646 features: "in situ" observations of the Menes caldera (NAUTINIL Expedition, 2003). Marine Geology.

648 Huguen, C. et al., 2004. Structural setting and tectonic control of mud volcanoes from the 649 Central Mediterranean Ridge (Eastern Mediterranean). Marine Geology, 209(1-4): $650 \quad 245-263$.

651 Huguen, C., Mascle, J., Woodside, J., Zitter, T. and Foucher, J.P., 2005. Mud volcanoes 652 and mud domes of the Central Mediterranean Ridge: Near-bottom and in situ 653 observations. Deep-Sea Research Part I Oceanographic Research Papers, 52(10): 654 1911-1931. 
655 Ishii, K., Mussmann, M., MacGregor, B.J. and Amann, R., 2004. An improved

656 fluorescence in situ hybridization protocol for the identification of bacteria and 657 archaea in marine sediments. FEMS Microbiology Ecology, 50(3): 203-213.

658 Iversen, N. and Blackburn, T.H., 1981. Seasonal rates of methane oxidation in anoxic 659 marine sediments. Applied and Environmental Microbiology, 41(6): 1295-1300.

660 Joye, S.B. et al., 2004. The anaerobic oxidation of methane and sulfate reduction in 661 sediments from Gulf of Mexico cold seeps. Chemical Geology, 205: 219-238.

662 Kallmeyer, J., Ferdelman, T.G., Weber, A., Fossing, H. and Jørgensen, B.B., 2004.

663 Evaluation of a cold chromium distillation procedure for recovering very small

664 amounts of radiolabeled sulfide related to sulfate reduction measurements. .

665 Limnology and Oceanography Methods, 2: 171-180.

666 Kane, M.D., Poulsen, L.K. and Stahl, D.A., 1993. Monitoring the enrichment and

667 isolation of sulfate-reducing bacteria by using oligonucleotide hybridization

668 probes designed from environmentally derived 16S rRNA sequences. Applied and $669 \quad$ Environmental Microbiology, 59: 682-686.

670 Kniemeyer, O. et al., 2007. Anaerobic oxidation of short-chain hydrocarbons by marine 671 sulphate-reducing bacteria. Nature, 449(7164): 898-U10.

672 Knittel, K. et al., 2003. Activity, distribution, and diversity of sulfate reducers and other 673 bacteria in sediments above gas hydrate (Cascadia margin, Oregon).

674 Geomicrobiology Journal, 20(4): 269-294.

675 Knittel, K., Losekann, T., Boetius, A., Kort, R. and Amann, R., 2005. Diversity and 676 distribution of methanotrophic archaea at cold seeps. Applied and Environmental 677 Microbiology, 71(1): 467-479. 
678 Lane, D.J. et al., 1985. Rapid-Determination of 16s Ribosomal-Rna Sequences for 679 Phylogenetic Analyses. Proceedings of the National Academy of Sciences of the $680 \quad$ United States of America, 82(20): 6955-6959.

681 Levin, L.A., 2005. Ecology of cold seep sediments: Interactions of fauna with flow, 682 chemistry and microbes. Oceanography and Marine Biology - an Annual Review,

684 Loncke, L., Gaullier, V., Mascle, J., Vendeville, B. and Camera, L., 2006. The Nile deep685 sea fan: An example of interacting sedimentation, salt tectonics, and inherited subsalt paleotopographic features. Marine and Petroleum Geology, 23(3): 297-

Loncke, L., Mascle, J. and Fanil Scientific Parties, 2004. Mud volcanoes, gas chimneys, 315. pockmarks and mounds in the Nile deep-sea fan (Eastern Mediterranean):

691 Lösekann, T. et al., 2007. Diversity and Abundance of Aerobic and Anaerobic Methane Oxidizers at the Haakon Mosby Mud Volcano, Barents Sea. Applied and Environmental Microbiology. Applied and Environmental Microbiology, 73:

695 Ludwig, W. et al., 2004. ARB: a software environment for sequence data. Nucleic Acids 696 Research, 32(4): 1363-1371.

697 Luff, R. and Wallmann, K., 2003. Fluid flow, methane fluxes, carbonate precipitation and 698 biogeochemical turnover in gas hydrate-bearing sediments at Hydrate Ridge, 699 Cascadia Margin: numerical modeling and mass balances. Geochimica et $700 \quad$ Cosmochimica Acta, 67(18): 3403-3421. 
701 Mascle, J., Loncke, L. and Camera, L., 2005. Geophysical evidences of fluid seepages

702 and mud volcanoes on the Egyptian continental margin (Eastern Mediterranean).

703 Bollettino Della Societa Geologica Italiana: 127-134.

704 Mascle, J. et al., 2006. Morphostructure of the Egyptian continental margin: Insights

705 from swath bathymetry surveys. Marine Geophysical Researches, 27(1): 49-59.

706 Mascle, J. et al., 2001. The Nile deep sea fan: preliminary results from a swath

707 bathymetry survey. Marine and Petroleum Geology, 18(4): 471-477.

708 Massana, R., Murray, A.E., Preston, C.M. and DeLong, E.F., 1997. Vertical distribution

709 and phylogenetic characterization of marine planktonic Archaea in the Santa

710 Barbara Channel. Applied and Environmental Microbiology, 63(1): 50-56.

711 Michaelis, W. et al., 2002. Microbial reefs in the Black Sea fueled by anaerobic oxidation

712 of methane. Science, 297: 1013-1015.

713 Mills, H.J., Martinez, R.J., Story, S. and Sobecky, P.A., 2005. Characterization of

714 microbial community structure in Gulf of Mexico gas hydrates: Comparative

715 analysis of DNA- and RNA-derived clone libraries. Applied and Environmental

$716 \quad$ Microbiology, 71(6): 3235-3247.

717 Muyzer, G., Teske, A., Wirsen, C.O. and Jannasch, H.W., 1995. Phylogenetic-

718 Relationships of Thiomicrospira Species and Their Identification in Deep-Sea

719 Hydrothermal Vent Samples by Denaturing Gradient Gel-Electrophoresis of 16s

720 Rdna Fragments. Archives of Microbiology, 164(3): 165-172.

721 Niemann, H. et al., 2006a. Microbial methane turnover at mud volcanoes of the Gulf of

722 Cadiz. Geochimica et Cosmochimica Acta, 70(21): 5336. 
723 Niemann, H. et al., 2006b. Novel microbial communities of the Haakon Mosby mud

$724 \quad$ volcano and their role as a methane sink. Nature, 443(7113): 854.

725 Nubel, U., Garcia-Pichel, F., Clavero, E. and Muyzer, G., 2000. Matching molecular

726 diversity and ecophysiology of benthic cyanobacteria and diatoms in communities

727 along a salinity gradient. Environ Microbiol, 2(2): 217-226.

728 Olu-Le Roy, K. et al., 2004. Cold seep communities in the deep eastern Mediterranean

729 Sea: composition, symbiosis and spatial distribution on mud volcanoes. Deep-Sea

730 Research Part I: Oceanographic Research Papers, 51(12): 1915-1936.

731 Omoregie, E.O. et al., 2008. Biogeochemistry and community composition of iron- and

732 sulfur-precipitating microbial mats at the Chefren mud volcano Applied and

733 Environmental Microbiology, 74(10): 3198-3215.

734 Orphan, V.J., House, C.H., Hinrichs, K.-U., McKeegan, K.D. and De Long, E.F., 2001.

735 Methane-consuming Archaea revealed by directly coupled isotopic and

$736 \quad$ phylogenetic analysis. Science, 293: 484-487.

737 Pancost, R.D. et al., 2000. Biomarker evidence for widespread anaerobic methane

$738 \quad$ oxidation in Mediterranean sediments by a consortium of methanogenic archaea

739 and bacteria. Applied and Environmental Microbiology, 66(3): 1126-1132.

740 Pernthaler, A. et al., 2008. Diverse syntrophic partnerships from-deep-sea methane vents

741 revealed by direct cell capture and metagenomics. Proceedings of the National

$742 \quad$ Academy of Sciences of the United States of America, 105(19): 7052-7057.

743 Pernthaler, A., Pernthaler, J. and Amann, R., 2002. Fluorescence in situ hybridization and

744 catalyzed reporter deposition (CARD) for the identification of marine Bacteria.

745 Applied and Envrionmental Microbiol(68): 3094-3101. 
746 Reeburgh, W.S., 2007. Oceanic methane biogeochemistry. Chemical Reviews, 107(2):

$747 \quad 486-513$.

748 Ritger, S., Carson, B. and Suess, E., 1987. Methane-Derived Authigenic Carbonates

749 Formed by Subduction Induced Pore-Water Expulsion Along the Oregon

750 Washington Margin. Geological Society of America Bulletin, 98(2): 147-156.

751 Sahling, H., Rickert, D., Lee, R.W., Linke, P. and Suess, E., 2002. Macrofaunal

752 community structure and sulfide flux at gas hydrate deposits from the Cascadia

753 convergent margin, NE Pacific. Marine Ecology Progress Series, 231: 121-138.

754 Schloss, P.D., Larget, B.R. and Handelsman, J., 2004. Integration of microbial ecology

755 and statistics: a test to compare gene libraries. Applied and Environmental

$756 \quad$ Microbiology, 70(9): 5485-5492.

757 Sibuet, M. and Olu-Le Roy, K., 2002. Cold Seep Communities on Continental Margins:

758 Structure and Quantitative Distribution Relative to Geological and Fluid Venting

759 Patterns, Ocean Margin System. Springer Verlag, pp. 235-251.

760 Sibuet, M. and Olu, K., 1998. Biogeography, biodiversity and fluid dependence of deep-

761 sea cold-seep communities at active and passive margins. Deep-Sea Research Part

762 II: Topical Studies in Oceanography, 45(1-3): 517-567.

763 Snaidr, J., Amann, R., Huber, I., Ludwig, W. and Schleifer, K.H., 1997. Phylogenetic

764 analysis and in situ identification of bacteria in activated sludge. Applied and

$765 \quad$ Environmental Microbiology, 63(7): 2884-2896.

766 Tina Lösekann et al., 2007. Diversity and abundance of aerobic and anaerobic methane

767 oxidizers at the Haakon Mosby Mud Volcano, Barents Sea Applied and

$768 \quad$ Environmental Microbiology, 73: 3348-3362. 
769 Treude, T., Boetius, A., Knittel, K., Wallmann, K. and Jørgensen, B.B., 2003. Anaerobic

770 oxidation of methane above gas hydrates at Hydrate Ridge, NE Pacific Ocean.

$771 \quad$ Marine Ecology Progress Series, 264: 1-14.

772 Wallmann, K. et al., 1997. Quantifying fluid flow, solute mixing, and biogeochemical

773 turnover at cold vents of the eastern Aleutian subduction zone. Geochim.

774 Cosmochim. Acta, 61(24): 5209-5219.

775 Widdel, F., Musat, F., Knittel, K. and Galushko, A., 2006/2007. Anaerobic degradation

776 of hydrocarbons with sulphate as electron acceptor. In: L. Barton, L. and W.A.

777 Hamilton (Editors), Sulphate-Reducing Bacteria: Environmental and Engineered

$778 \quad$ Systems. Cambridge University Press.

779 Widdel, F. and Rabus, R., 2001. Anaerobic biodegradation of saturated and aromatic

780 hydrocarbons. Current Opinion in Biotechnology, 12(3): 259-276.

781 Woodside, J.M., Ivanov, M.K., Limonov, A.F. and Shipboard Scientist of the, A.E., 1998.

782 Shallow gas and gas hydrates in the Anaximander Mountains region, eastern

783 Mediterranean Sea. Geological Society, London, Special Publications, 137(1):

$784 \quad 177-193$.

785 Zitter, T.A.C., Huguen, C. and Woodside, J.M., 2005. Geology of mud volcanoes in the

786 eastern Mediterranean from combined sidescan sonar and submersible surveys.

787 Deep-Sea Research Part I: Oceanographic Research Papers, 52(3): 457-475.

788

789 
790 Table 1. Sediment cores, and analysis conducted within this study. Latitude and longitude are given in degrees and decimal minutes.

\begin{tabular}{|c|c|c|c|c|c|c|c|c|c|c|c|c|c|}
\hline Dive & Location $^{\text {a }}$ & Site & Latitude & Longitude & Depth (m) & Core ID & $\mathrm{SO}_{4}{ }^{2-}$ & $\mathrm{CH}_{4}$ & SR & AOM & $16 S$ & FISH & Dive observation \\
\hline 11 & $\bar{E}$ & Amon, SE center & $32^{\circ} 22.1444$ & $31^{\circ} 42.6481$ & 1121 & NL11PC1 & $\mathrm{x}$ & $x$ & $\mathrm{x}$ & $\mathrm{x}$ & - & - & sulfide oxidizing mat \\
\hline 12 & $\mathrm{E}$ & Amon, SW center & $32^{\circ} 22.1418$ & $31^{\circ} 42.5926$ & 1120 & NL12PC2 & $\mathrm{x}$ & $\mathrm{x}$ & $\mathrm{x}$ & $\mathrm{x}$ & $\mathrm{x}$ & $\mathrm{x}$ & sulfide oxidizing mat \\
\hline 8 & $\mathrm{E}$ & Isis, center & $32^{\circ} 21.6619$ & $31^{\circ} 23.3714$ & 992 & NL8PC1(4) & - & $\mathrm{x}$ & $\mathrm{x}$ & $\mathrm{x}$ & - & - & sulfide oxidizing mat \\
\hline 8 & $\mathrm{E}$ & Isis, center & $32^{\circ} 21.6678$ & $31^{\circ} 23.3572$ & 992 & NL8PC3(1) & $\mathrm{x}$ & $\mathrm{x}$ & $\mathrm{x}$ & $\mathrm{x}$ & - & - & gas saturated grayish sediment \\
\hline 13 & E & Isis, NW center & $32^{\circ} 21.6779$ & $31^{\circ} 23.3370$ & 991 & NL13PC4(7) & $\mathrm{x}$ & $\mathrm{x}$ & $\mathrm{x}$ & $\mathrm{x}$ & $\mathrm{x}$ & $\mathrm{x}$ & sulfide oxidizing mat \\
\hline 6 & $\mathrm{C}$ & Pockmarks, middle slope & $32^{\circ} 38.1418$ & $29^{\circ} 56.1236$ & 2114 & NL6PC1 & $\mathrm{x}$ & $\mathrm{x}$ & $\mathrm{x}$ & $\mathrm{x}$ & - & - & within a pockmark \\
\hline 7 & $\mathrm{C}$ & Pockmarks, middle slope & $32^{\circ} 31.6062$ & $30^{\circ} 20.6553$ & 1691 & NL7PC1 & - & $\mathrm{x}$ & $\mathrm{x}$ & $\mathrm{x}$ & - & - & away from pockmarks and carbonate \\
\hline 14 & $\mathrm{C}$ & Pockmarks, lower slope & $32^{\circ} 38.4402$ & $29^{\circ} 54.9764$ & 2127 & NL14PC2 & - & $\mathrm{x}$ & $\mathrm{x}$ & $\mathrm{x}$ & - & $\mathrm{x}$ & close to carbonate \\
\hline 15 & $\mathrm{C}$ & North Alex, E center & $31^{\circ} 58.1897$ & $30^{\circ} 08.2229$ & 507 & NL15BC1 & $\mathrm{x}$ & $\mathrm{x}$ & $\mathrm{x}$ & $\mathrm{x}$ & $\mathrm{x}$ & - & grey sediment without mats \\
\hline 4 & W & Chefren, NW slope & $32^{\circ} .067373$ & $28^{\circ} 10.3497$ & 3023 & NL4PC1 & - & $\mathrm{x}$ & $\mathrm{x}$ & $\mathrm{x}$ & - & - & sulfide oxidizing mat \\
\hline 18 & $\mathrm{~W}$ & Chefren, NW slope & $32^{\circ} 06.7406$ & $28^{\circ} 10.3487$ & 3024 & NL18PC2(7) & $\mathrm{x}$ & $\mathrm{x}$ & $\mathrm{x}$ & $\mathrm{x}$ & $\mathrm{x}$ & $\mathrm{x}$ & iron oxidizing mat \\
\hline 18 & W & Chefren, NW slope & $32^{\circ} 06.7397$ & $28^{\circ} 10.3510$ & 3022 & NL18PC4(6) & $\mathrm{x}$ & $\mathrm{x}$ & $\mathrm{x}$ & $\mathrm{x}$ & $\mathrm{x}$ & $\mathrm{x}$ & sulfide oxidizing mat \\
\hline 19 & W & Chefren, S center & $32^{\circ} 06.4872$ & $28^{\circ} 10.6767$ & 2968 & NL19PC1(5) & $\mathrm{x}$ & $\mathrm{x}$ & $\mathrm{x}$ & $\mathrm{x}$ & - & - & the edge of a brine lake \\
\hline 19 & W & Chefren, $\mathrm{S}$ center & $33^{\circ} 06.4872$ & $28^{\circ} 10.6774$ & 2968 & NL19PC3(8) & $\mathrm{x}$ & - & $\mathrm{x}$ & $\mathrm{x}$ & - & $\mathrm{x}$ & the edge of a brine lake \\
\hline 1 & MR & Napoli, center & $33^{\circ} 43.4759$ & $24^{\circ} 41.0472$ & 1939 & NL1PC2 & $\mathrm{x}$ & $\mathrm{x}$ & $\mathrm{x}$ & $\mathrm{x}$ & - & $\mathrm{x}$ & sulfide oxidizing mat \\
\hline 21 & MR & Napoli, NW center & $33^{\circ} 43.6553$ & $24^{\circ} 40.8541$ & 1946 & NL21PC5(1) & & & $\mathrm{x}$ & $\mathrm{x}$ & - & - & sulfide oxidizing mat \\
\hline 21 & MR & Napoli, NW center & $34^{\circ} 43.6553$ & $24^{\circ} 40.8541$ & 1946 & NL21PC6(2) & $\mathrm{x}$ & $\mathrm{x}$ & $\mathrm{x}$ & $\mathrm{x}$ & - & - & sulfide oxidizing mat \\
\hline 22 & MR & Napoli, S center & $33^{\circ} 43.3569$ & $24^{\circ} 41.0522$ & 1940 & NL22PC7(3) & $\mathrm{x}$ & $\mathrm{x}$ & $\mathrm{x}$ & $\mathrm{x}$ & - & - & sulfide oxidizing mat \\
\hline
\end{tabular}

792 a. Location within the Eastern (E), Central (C) and Western (W) Nile Deep-Sea fan, as well as the Mediterranean Ridge (MR). 
794 Table 2. Oligonucleotide probes and hybridization conditions used in this study. EUB-I, II, III were mixed into a single solution.

\begin{tabular}{|c|c|c|c|c|c|c|}
\hline Probe & Target Group & Sequence (5' to 3') & Type & \%Formamid & ${ }^{\circ} \mathrm{C}$ Hybrid/Wash & Reference \\
\hline ARCH915 & Most Archaea & GTGCTCCCCCGCCAATTCCT & CARD & 35 & $46 / 48$ & Amann et al. 1990 \\
\hline ANME-1-350 & ANME-1 & AGTTTTCGCGCCTGATGC & CARD & 40 & $46 / 48$ & Boetius et al. 2000 \\
\hline ANME-2-538 & ANME-2 & GGCTACCACTCGGGCCGC & FISH & 50 & $46 / 48$ & Treude et al. 2005 \\
\hline ANME-3-1249 & ANME-3 & TCGGAGTAGGGACCCATT & CARD & 20 & $46 / 48$ & Lösekann et al. 2007 \\
\hline EUB I & Most bacteria & GCTGCCTCCCGTAGGAGT & CARD & 35 & $46 / 48$ & Amann et al. 1990 \\
\hline EUB II & Planctomycetales & GCAGCCACCCGTAGGTGT & CARD & 35 & $46 / 48$ & Daims et al. 1999 \\
\hline EUB III & Verrucomicrobiales & GCTGCCACCCGTAGGTGT & CARD & 35 & $46 / 48$ & Daims et al. 1999 \\
\hline Non338 & negative hybridization probe & ACTCCTACGGGAGGCAGC & CARD/FISH & variable & $46 / 48$ & Wallner et al. 1993 \\
\hline DSS658 & Desulfosarcina-Desulfococcus & ТССАСТТСССТСТСССАТ & CARD & 50 & $46 / 48$ & Manz et al. 1998 \\
\hline 660 & Desulfobulbus & GAАTTССАСТTТССССТСТG & CARD & 60 & $46 / 48$ & Devereux et al. 1992 \\
\hline M $\gamma 705$ & Type I Methanotrophs & CTGGTGTTCCTTCAGATC & FISH & 20 & $46 / 48$ & Gulledge et al. 1992 \\
\hline
\end{tabular}


797 Table 3. Depth integrated sulfate reduction (SR) and anaerobic oxidation of methane (AOM) rates in different sediment horizons

$798\left(\mathrm{mmol} \times \mathrm{m}^{-2} \times \mathrm{d}^{-1}\right) . \quad "<$ indicates less than $0.01 \mathrm{mmol} \times \mathrm{m}^{-2} \times \mathrm{d}^{-1}$.

\begin{tabular}{|c|c|c|c|c|c|c|c|c|c|c|c|c|c|c|}
\hline Location & Core & SR(0-4) & $\operatorname{AOM}(0-4)$ & SR/AOM & SR (4-10) & $\operatorname{AOM}(4-10)$ & SR/AOM & SR(0-10) & $\operatorname{AOM}(0-10)$ & SR/AOM & SR (10-) & $\operatorname{AOM}(10-)$ & SR/AOM & core depth \\
\hline Amon & NL11PC1 & 2.0 & 0.1 & 15 & 8.5 & 3.0 & 3 & 10.5 & 3.1 & 3 & 10.7 & 0.8 & 14 & $(23 \mathrm{~cm})$ \\
\hline Amon & NL12PC2 & 9.9 & 2.2 & 5 & 6.8 & 3.7 & 2 & 16.7 & 5.8 & 3 & 2.8 & 0.8 & 3 & $(15 \mathrm{~cm})$ \\
\hline Isis & NL8PC1(4) & 3.2 & 0.2 & 14 & 0.7 & 0.1 & 6 & 3.8 & 0.3 & 12 & - & - & - & \\
\hline Isis & NL8PC3(1) & 3.3 & 0.2 & 14 & 5.3 & 0.1 & 57 & 8.6 & 0.3 & 26 & - & - & - & \\
\hline Isis & NL13PC4(7) & 24.8 & 1.5 & 17 & 19.1 & 2.1 & 9 & 44.0 & 3.6 & 12 & - & - & - & \\
\hline Pockmarks & NL6PC1 & 0.1 & $<$ & - & $<$ & $<$ & - & 0.1 & $<$ & - & - & - & - & \\
\hline Pockmarks & NL7PC1 & $<$ & $<$ & - & $<$ & $<$ & - & $<$ & $<$ & - & - & - & - & \\
\hline Pockmarks & NL14PC2 & 0.1 & 0.1 & 1 & 0.1 & $<$ & - & 0.1 & 0.1 & 2 & 2.8 & $<$ & - & $(21 \mathrm{~cm})$ \\
\hline North Alex & NL15BC1 & 1.2 & 0.9 & 1 & 2.8 & 2.5 & 1 & 4.0 & 3.5 & 1 & - & - & - & \\
\hline Chefren & NL4PC1 & 42.7 & 0.6 & 72 & 23.9 & 0.3 & 79 & 66.5 & 0.9 & 75 & 2.1 & 0.2 & 10 & $(25 \mathrm{~cm})$ \\
\hline Chefren & NL18PC4(6) & 4.1 & 0.1 & 72 & 0.3 & 0.1 & 3 & 4.4 & 0.2 & 28 & - & - & - & \\
\hline Chefren & NL18PC2(7) & 0.8 & 0.2 & 4 & 4.6 & 0.3 & 16 & 5.3 & 0.5 & 11 & 0.6 & 0.1 & 6 & $(15 \mathrm{~cm})$ \\
\hline Chefren & NL19PC3(8) & 0.2 & 0.2 & 1 & $<$ & 0.1 & - & 0.2 & 0.3 & 1 & - & - & - & \\
\hline Chefren & NL19PC1(5) & 0.5 & 1.2 & - & 0.1 & 1.1 & - & 0.7 & 2.3 & - & - & - & - & \\
\hline Napoli & NL1PC2 & 8.7 & $<$ & - & 0.1 & $<$ & - & 8.8 & $<$ & - & - & - & - & \\
\hline Napoli & NL21PC6(2) & 2.0 & $<$ & - & 0.1 & $<$ & - & 2.1 & $<$ & - & - & - & - & \\
\hline Napoli & NL21PC5(1) & 4.4 & 0.1 & 70 & 3.6 & $<$ & - & 8.0 & 0.1 & 87 & 27.1 & $<$ & - & $(13 \mathrm{~cm})$ \\
\hline Napoli & NL22PC7(3) & 0.6 & $<$ & - & 3.6 & $<$ & - & 4.2 & $<$ & - & - & - & - & \\
\hline
\end{tabular}


801 Table 4. Cell numbers as well as FISH counts for Archaea and Bacteria. ANME-3-1249 and 660 targeted cells were less than $1 \%$ of

802 total cell numbers. Numbers are per ml of sediment.

\begin{tabular}{|c|c|c|c|c|c|c|c|c|c|c|c|c|c|c|c|c|c|c|c|c|}
\hline & \multirow[b]{2}{*}{ Depth } & \multirow[b]{2}{*}{$\begin{array}{c}\text { Total Cells } \\
1 \times 109\end{array}$} & \multicolumn{3}{|c|}{ ARC915 } & \multicolumn{3}{|c|}{ ANME-1 } & \multicolumn{3}{|c|}{ ANME-2 } & \multicolumn{3}{|c|}{ EUBI-III } & \multicolumn{3}{|c|}{ DSS658 } & \multicolumn{3}{|c|}{ M 705} \\
\hline & & & \begin{tabular}{|c} 
Free Cells \\
$1 \times 10^{9}$
\end{tabular} & $\begin{array}{c}\text { Cells in } \\
\text { Agg1 } 1 \times 10^{9}\end{array}$ & $\begin{array}{c}\text { Percent } \\
\text { Total }\end{array}$ & \begin{tabular}{|c|} 
Free Cells \\
$1 \times 10^{9}$
\end{tabular} & $\begin{array}{c}\text { Cells in } \\
\text { Agg1 } 110^{9}\end{array}$ & $\begin{array}{c}\text { Percent } \\
\text { Total }\end{array}$ & $\begin{array}{c}\text { Free Cells } \\
1 \times 10^{9}\end{array}$ & $\begin{array}{c}\text { Cells in } \\
\text { Agg } 1 \times 10^{9}\end{array}$ & $\begin{array}{c}\text { Percent } \\
\text { Total }\end{array}$ & $\begin{array}{c}\text { Free Cells } \\
1 \times 10^{9}\end{array}$ & $\begin{array}{c}\text { Cells in } \\
\text { Agg1 } 1010^{9}\end{array}$ & $\begin{array}{l}\text { Percent } \\
\text { Total }\end{array}$ & $\begin{array}{c}\text { Free Cells } \\
1 \times 10^{9}\end{array}$ & $\begin{array}{c}\text { Cells in } \\
\text { Agg1 } 1 \times 10^{9}\end{array}$ & $\begin{array}{c}\text { Percent } \\
\text { Total }\end{array}$ & \begin{tabular}{|c} 
Free Cells \\
$1 \times 10^{9}$
\end{tabular} & $\begin{array}{c}\text { Cells in } \\
\text { Agg } 1 \times 10^{9}\end{array}$ & $\begin{array}{c}\text { Percent } \\
\text { Total }\end{array}$ \\
\hline \multirow{3}{*}{$\begin{array}{l}\text { Amon } \\
\text { NL12PC1 }\end{array}$} & $0-2 \mathrm{~cm}$ & 8.03 & 0.05 & 3.38 & 43 & $<$ & $<$ & $<$ & $<$ & 1.79 & 22 & 0.99 & 3.38 & 54 & 0.05 & 3.98 & 50 & $<$ & $<$ & $<$ \\
\hline & $2-4 \mathrm{~cm}$ & 7.40 & 0.06 & 3.13 & 43 & $<$ & $<$ & $<$ & $<$ & 0.76 & 10 & 0.95 & 3.13 & 55 & 0.08 & 2.27 & 32 & $<$ & $<$ & $<$ \\
\hline & $10-12 \mathrm{~cm}$ & 0.30 & 0.01 & 0.00 & 5 & $<$ & $<$ & $<$ & $<$ & $<$ & $<$ & 0.11 & 0.00 & 38 & 0.01 & nd & 2 & $<$ & $<$ & $<$ \\
\hline Isis & $0-2 \mathrm{~cm}$ & 4.87 & 0.26 & 1.33 & 33 & $<$ & $<$ & $<$ & $<$ & 0.54 & 11 & 1.65 & 1.33 & 61 & 0.09 & 0.06 & 3 & $<$ & $<$ & $<$ \\
\hline \multirow{2}{*}{ NL13PC4(7) } & $2-4 \mathrm{~cm}$ & 7.44 & 0.05 & 3.02 & 41 & $<$ & $<$ & $<$ & $<$ & 2.56 & 34 & 0.73 & 3.02 & 50 & 0.21 & 0.01 & 3 & $<$ & $<$ & $<$ \\
\hline & $10-12 \mathrm{~cm}$ & 3.96 & 0.11 & 1.44 & 39 & $<$ & $<$ & $<$ & $<$ & - & - & 0.86 & 1.44 & 58 & 0.07 & 0.01 & 2 & $<$ & $<$ & $<$ \\
\hline PockM & $0-2 \mathrm{~cm}$ & 0.67 & 0.11 & $<$ & 17 & $<$ & $<$ & $<$ & $<$ & $<$ & $<$ & 0.32 & $<$ & 47 & $<$ & $<$ & & $<$ & $<$ & $<$ \\
\hline \multirow{2}{*}{ NL14PC2 } & $2-4 \mathrm{~cm}$ & 0.88 & 0.02 & $<$ & 2 & $<$ & $<$ & $<$ & $<$ & $<$ & $<$ & 0.22 & $<$ & 24 & $<$ & $<$ & & 0.01 & $<$ & 2 \\
\hline & $10-12 \mathrm{~cm}$ & 0.41 & 0.01 & $<$ & 3 & $<$ & $<$ & $<$ & $<$ & $<$ & $<$ & 0.08 & $<$ & 19 & $<$ & $<$ & & & $<$ & $<$ \\
\hline \multirow{3}{*}{$\begin{array}{l}\text { North A. } \\
\text { NL15BC1 }\end{array}$} & $0-2 \mathrm{~cm}$ & 352 & 011 & 050 & 17 & 0.02 & $<$ & 0 & $<$ & 0.46 & 13 & 208 & 0,50 & 73 & 025 & 0.02 & 7 & $<$ & $<$ & $<$ \\
\hline & $2-4 \mathrm{~cm}$ & $\begin{array}{l}3.52 \\
3.62\end{array}$ & 0.04 & 0.41 & 13 & $\begin{array}{l}0.02 \\
0.01\end{array}$ & $<$ & 0 & $<$ & $<.40$ & $<$ & $\begin{array}{l}2.00 \\
2.44\end{array}$ & 0.41 & 79 & 0.30 & 0.00 & 8 & $<$ & $<$ & $<$ \\
\hline & $10-12 \mathrm{~cm}$ & 2.70 & 0.09 & 0.55 & 24 & 0.03 & $<$ & 1 & $<$ & 0.18 & 7 & 0.16 & 0.55 & 27 & 0.06 & 0.00 & 3 & $<$ & $<$ & $<$ \\
\hline & $0-2 \mathrm{~cm}$ & 0.90 & 0.06 & $<$ & 7 & $<$ & $<$ & $<$ & $<$ & $<$ & $<$ & 0.47 & $<$ & 52 & 0.21 & $<$ & 23 & $<$ & $<$ & $<$ \\
\hline \multirow{2}{*}{ NL18PC4(6) } & $2-4 \mathrm{~cm}$ & 2.10 & 0.07 & 0.59 & 32 & $<$ & $<$ & $<$ & $<$ & 0.38 & 18 & 0.49 & 0.59 & 51 & 0.16 & 0.29 & 22 & $<$ & $<$ & $<$ \\
\hline & $10-12 \mathrm{~cm}$ & 0.42 & 0.07 & $<$ & 17 & $<$ & $<$ & $<$ & $<$ & $<$ & $<$ & 0.13 & $<$ & 30 & $<$ & $<$ & $<$ & $<$ & $<$ & $<$ \\
\hline & $0-2 \mathrm{~cm}$ & 1.28 & 0.02 & 0.07 & 7 & $<$ & $<$ & $<$ & $<$ & 0.10 & 8 & 0.77 & $\begin{array}{c}\mathrm{z} \\
0.07\end{array}$ & 66 & 0.13 & 0.07 & 16 & 0.03 & $<$ & 2 \\
\hline \multirow{2}{*}{$\begin{array}{l}\text { Cnerren } \\
\text { NL18PC2(7) }\end{array}$} & $2-4 \mathrm{~cm}$ & 4.76 & 0.27 & 0.84 & 23 & $<$ & $<$ & $<$ & $<$ & 0.96 & 20 & 1.09 & 0.84 & 41 & 0.09 & 1.92 & 42 & $<$ & $<$ & $<$ \\
\hline & $10-12 \mathrm{~cm}$ & 4.59 & 0.34 & $<$ & 7 & $<$ & $<$ & $<$ & $<$ & $<$ & $<$ & 0.16 & $<$ & 3 & 0.13 & $<$ & 3 & $<$ & $<$ & $<$ \\
\hline & $0-2 \mathrm{~cm}$ & 20.45 & 3.27 & 3.12 & 31 & 1.04 & $<$ & 5 & $<$ & $<$ & $<$ & 5.96 & 3.12 & 44 & 2.35 & $<$ & 11 & 0.06 & $<$ & 1 \\
\hline \multirow[t]{2}{*}{$\begin{array}{l}\text { NL1PC2 } \\
\text { lac }\end{array}$} & $2-4 \mathrm{~cm}$ & 1.80 & 0.32 & $<$ & 18 & 0.16 & $<$ & 9 & $<$ & $<$ & $<$ & 0.76 & $<$ & 42 & 0.13 & $<$ & 7 & 0.00 & $<$ & 1 \\
\hline & $10-12 \mathrm{~cm}$ & 1.99 & 0.66 & $<$ & 33 & 0.43 & $<$ & 22 & $<$ & $<$ & $<$ & 0.54 & $<$ & 27 & $<$ & $<$ & 0 & $<$ & $<$ & $<$ \\
\hline
\end{tabular}


804 Table 5. Breakdown of 16S rRNA gene sequences, in percentages obtained from selected

805 cores in this study. The first $4 \mathrm{~cm}$ of sediment was used to construct each library.

806

\begin{tabular}{|c|c|c|c|c|}
\hline Phylogenetic group & $\begin{array}{c}\text { Amon } \\
\text { (NL12PC1) }\end{array}$ & $\begin{array}{c}\text { Isis } \\
\text { (NL12PC1) } \\
\end{array}$ & $\begin{array}{c}\text { Chefren } \\
(\operatorname{NL18PC4(6))}\end{array}$ & $\begin{array}{c}\text { Chefren } \\
\text { (NL18PC2(7)) }\end{array}$ \\
\hline Total number of Bacterial clones & $\underline{79}$ & $\underline{64}$ & $\underline{83}$ & $\underline{88}$ \\
\hline \% Alphaproteobacteria & 1 & 5 & $\mathbf{0}$ & 1 \\
\hline \% Gammaproteobacteria & 25 & 20 & 8 & 34 \\
\hline \% Type I methanothrophs & 8 & 5 & 2 & 7 \\
\hline$\%$ Deltaproteobacteria & 58 & 36 & 42 & 31 \\
\hline \% SRB-1 DesulfosarcinalDesulfococcus & 25 & 19 & 14 & 9 \\
\hline$\%$ SRB-2 & 0 & 0 & 1 & 0 \\
\hline \% SRB-3 Desulfobulbus & 1 & 0 & 0 & 1 \\
\hline$\%$ SRB-4 & 5 & 2 & 1 & 1 \\
\hline \% Epsilonproteobacteria & 1 & 6 & $\mathbf{0}$ & 7 \\
\hline \% Other Bacteria & 13 & 33 & 42 & 22 \\
\hline$\%$ Unidentified Bacteria & 1 & $\mathbf{0}$ & 7 & 6 \\
\hline Total number of Archaeal clones & $\underline{68}$ & $\underline{71}$ & $\underline{71}$ & $\underline{66}$ \\
\hline \% Euryarcheaota & 100 & 97 & 94 & 98 \\
\hline$\%$ Methanococcoides & 3 & 1 & 0 & 0 \\
\hline$\%$ ANME-undesignated & 3 & 1 & 0 & 3 \\
\hline$\%$ ANME-2A & 51 & 31 & 18 & 52 \\
\hline$\%$ ANME-2C & 12 & 8 & 1 & 3 \\
\hline \% ANME-3 & 0 & 0 & 55 & 0 \\
\hline$\%$ MBG-D & 15 & 51 & 15 & 36 \\
\hline$\%$ unidentified Euryarcheaota & 16 & 4 & 6 & 5 \\
\hline$\%$ Crenarcheaota & $\mathbf{0}$ & 3 & 4 & 2 \\
\hline$\%$ MBG-B & 0 & 1 & 4 & 2 \\
\hline$\%$ MBG-1 & 0 & 1 & 0 & 0 \\
\hline
\end{tabular}


810 Figure 1. (A) Bathymetric map of the Eastern Mediterranean. Small and large rectangles

811 are the Olimpi mud volcano field and the Nile Deep Sea Fan, respectively. Numbers

812 indicate the locations of the Napoli (1), Chefren (2), North Alex (5), Isis (6), and Amon

813 (7) mud volcanoes as well as the pockmark region in the middle (3) and lower slope (4).

814 (B) 3D-Bathymetric map of Amon and Isis using an EM 12 dual system. After (Dupré et

815 al., 2007) (C) 3D-Bathymetric map of North Alex using an EM 12 dual system. (D) 3D-

816 Bathymetric map of the pockmarks region using an EM 12 dual system. After (Mascle et

817 al., 2006) (E) 3D-Bathymetric map of the Menes Caldera using an EM 12 dual system.

818 (F) 3D-Bathymetric map of Napoli using an EM 120 dual system. Depth scale bar not

819 shown, however, the summit of Napoli is about 1950 meters. Data collected in 2004 by

820 the Simed survey on board the B.O. "Beautemps-Beaupré". Numbers and lines in B,D,E

821 indicate cruise tracks and dive numbers.

823 Figure 2. Seafloor images taken by the submersible Nautile. (A) Troughs at the center of 824 Amon covered with sulfide oxidizing mats. (B) Troughs at the center of Isis covered with

825 sulfide-oxidizing mats. (C) Flat seabed at Isis with sulfide-oxidizing mats (NL8PC1(4), 826 NL13PC4(7)) and grey patches (NL8PC3(1)). (D) Carbonate crusts at the outer rim of 827 Amon.

828

829 Figure 3. Rates of sulfate reduction and anaerobic oxidation of methane, and profiles of 830 sulfate and methane concentrations from selected cores. Lines with triangles, squares and 
831 circles are replicate rate measurements, whereas solid lines are sulfate and methane

832 measurements. Core descriptions presented on the right next to geochemical gradients.

833 Pictograms used for core descriptions are below. (A) Core from sulfide oxidizing mat of

834 Amon (NL12PC1). (B) Core from sulfide oxidizing mat of Isis (NL13PC4(7).

835

836 Figure 4. Seafloor images taken by the submersible Nautile. (A) Flat seabed of North

837 Alex (NL15BC) exhibiting gas ebullition. (B) Edge of a pockmark from middle slope

838 (Dive NL7). (C) Carbonate pavement of the lower slope (NL14PC2). (D) Close up of

839 siboglinid worms and shell debris from a carbonate crust.

840

841 Figure 5. Rates of sulfate reduction and anaerobic oxidation of methane, and profiles of

842 sulfate and methane concentrations from selected cores. Lines with triangles, squares and

843 circles are replicate rate measurements, whereas solid lines are sulfate and methane

844 measurements. For legend see Figure 3. (A) Gas saturated sediment from North Alex

845 (NL15BC1). (B) Next to a carbonate crust (NL14PC1). Pictograms used for core

846 descriptions are below are provided in figure 3

848 Figure 6. Seafloor images taken by the submersible Nautile. (A) Brine pool at Chefren 849 covered with sulfide-oxidizing mats. (B) Sediment (upper left) and brine transition,

850 bisected by sulfide-oxidizing mats at Chefren (NL19PC1(5) and PC3(8)). (C) Brine lake

851 at Napoli. (D) Sulfide and iron oxidizing mats at Chefren (NL4PC1, NL18PC2(7),

852 PC4(6)). (E) Sulfide-oxidizing mats and reduced sediment at Napoli (NL1PC2,

853 NL21PC5(1), PC6(2) and NL22PC7(3)). (F) Carbonate crusts at Napoli. 
855 Figure 7. Rates of sulfate reduction and anaerobic oxidation of methane, and profiles of

856 sulfate and methane concentrations from selected cores. Lines with triangles, squares and

857 circles are replicate rate measurements, whereas solid lines are sulfate and methane

858 measurements. For legend see Figure 3. (A) Sulfide-oxidizing mat from Chefren

859 (NL18PC4(6)). (B) Iron-oxidizing mat from Chefren (NL18PC2(7)). (C) Sulfide-

860 oxidizing mat from Napoli (NL1PC2). Pictograms used for core descriptions are

861 provided in figure 3. 

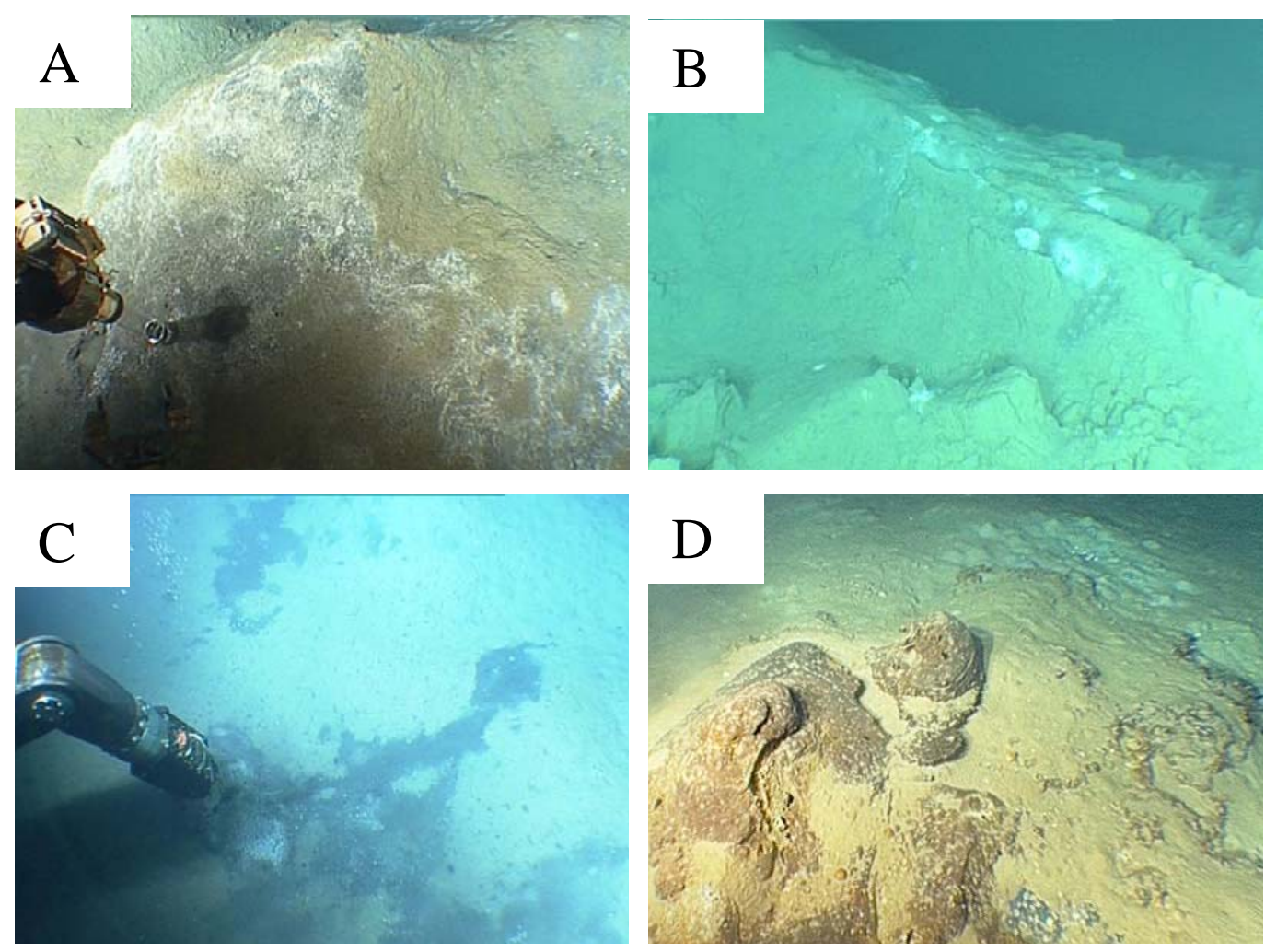

Figure 2 


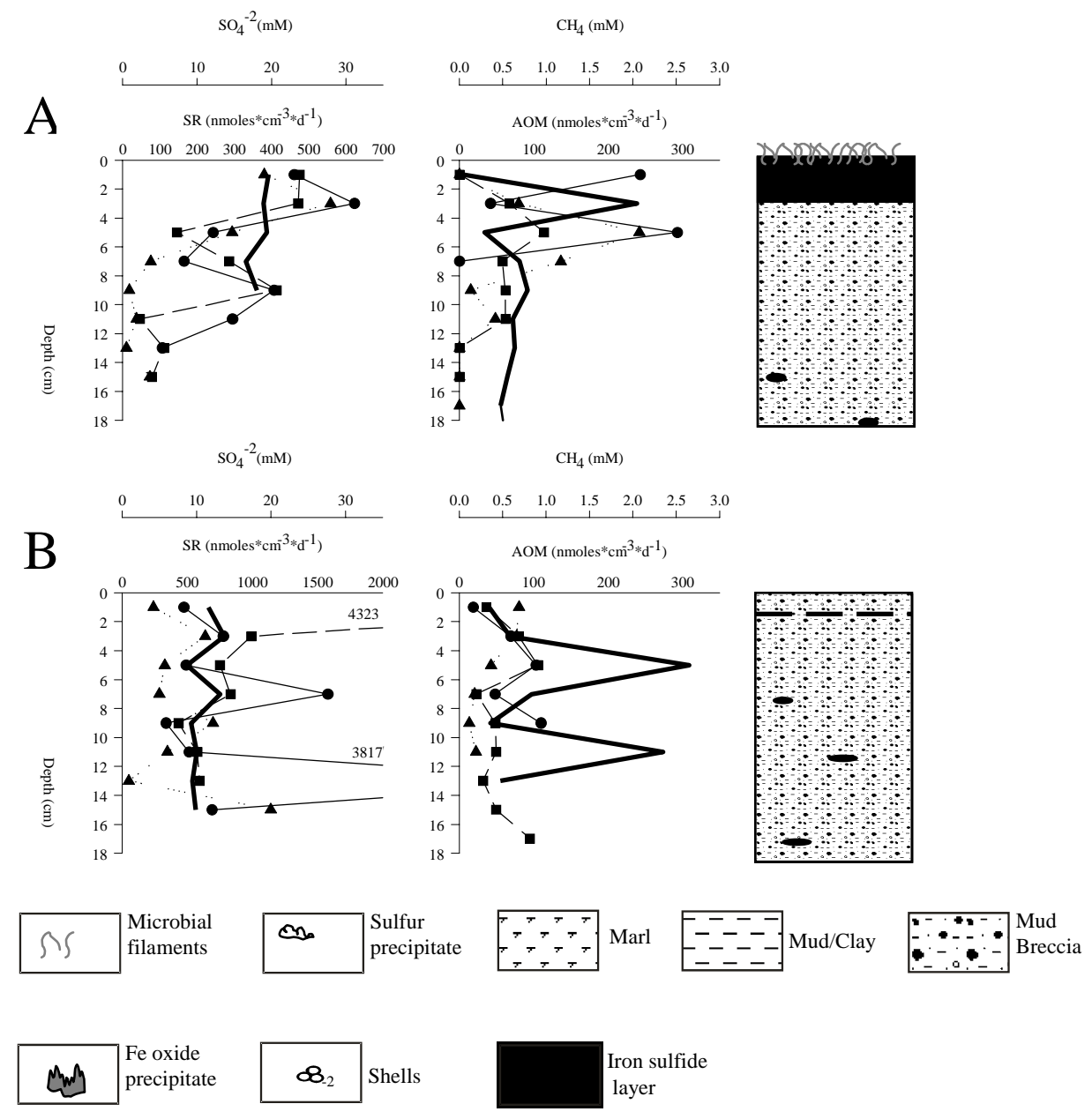

Figure 3 

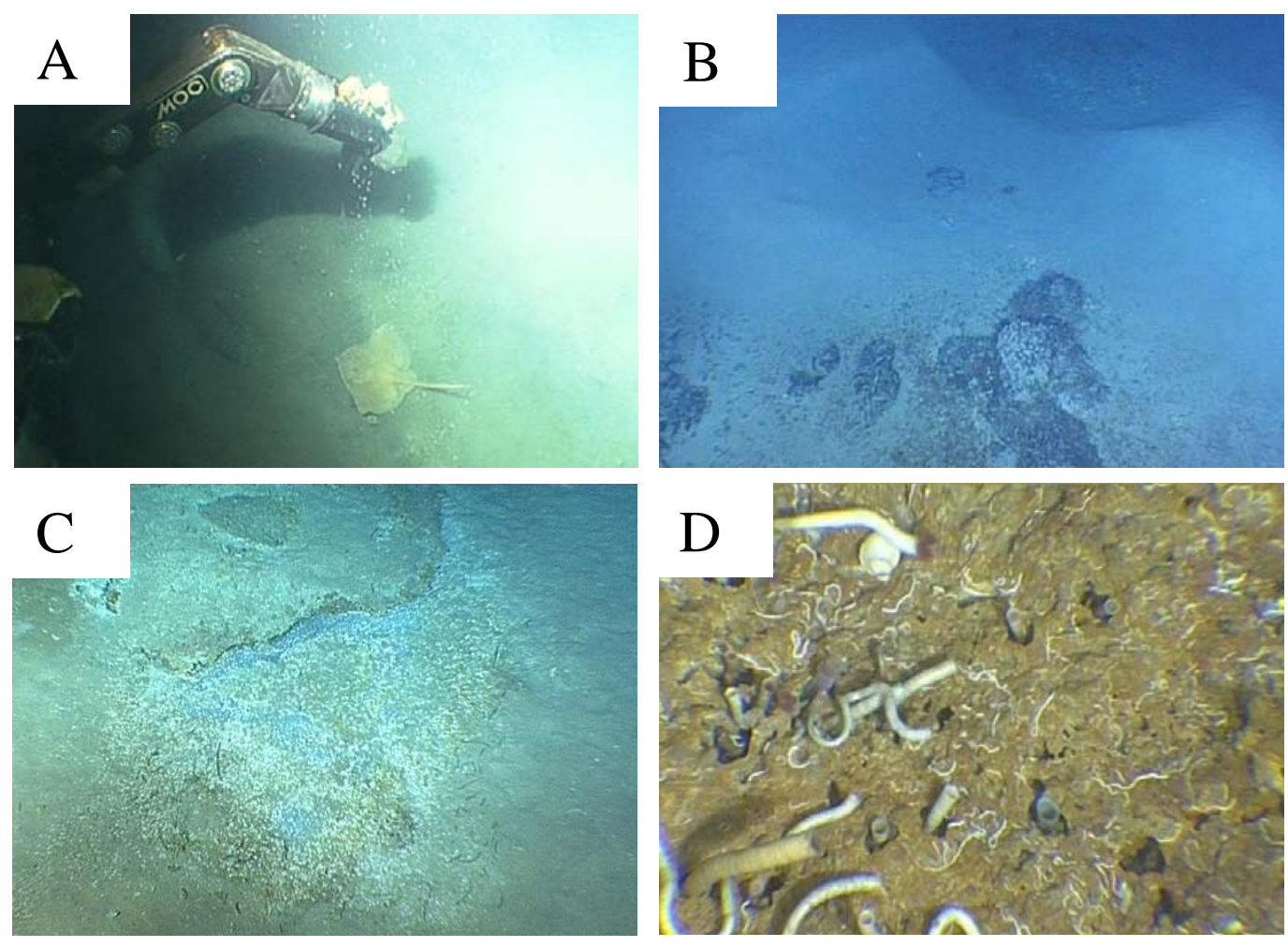

Figure 4 


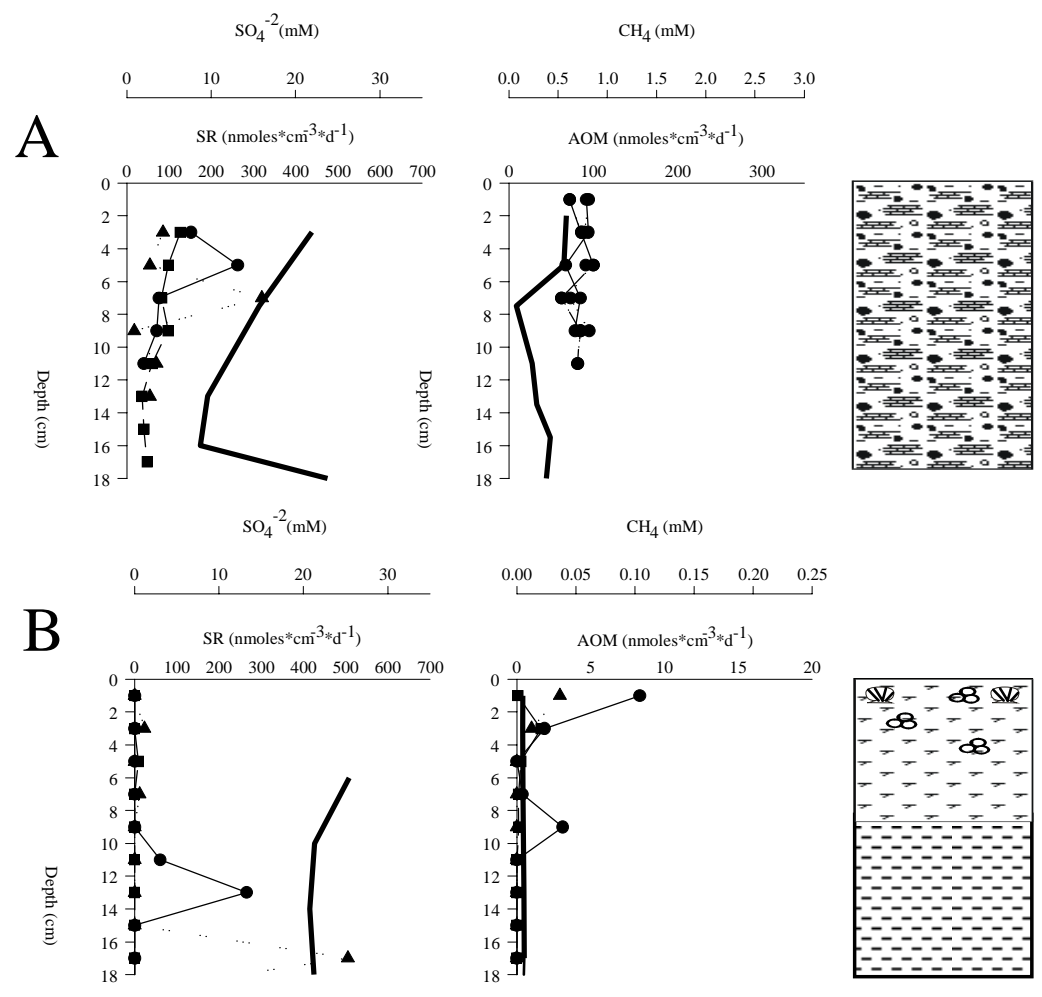

Figure 5 

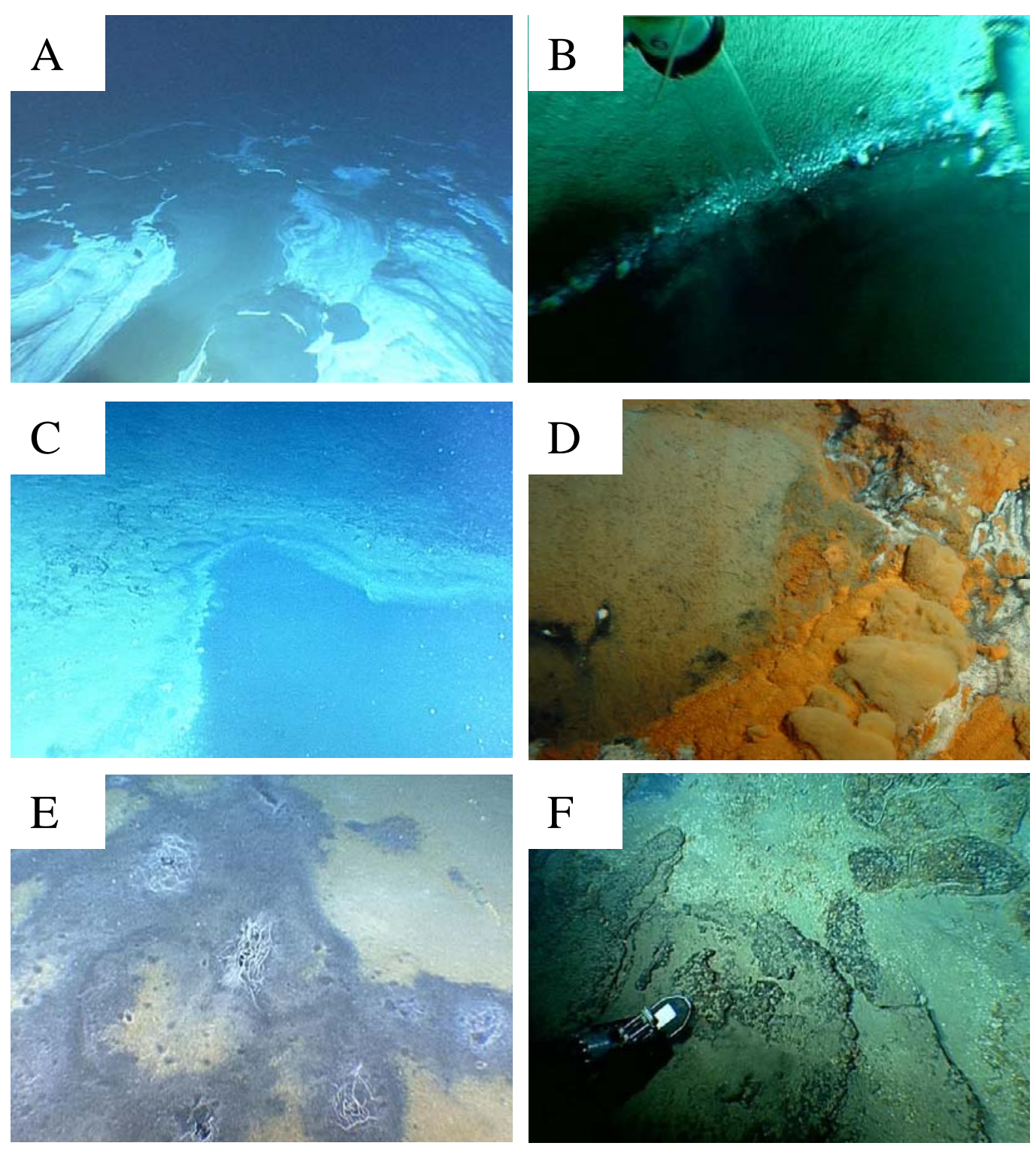

Figure 6 


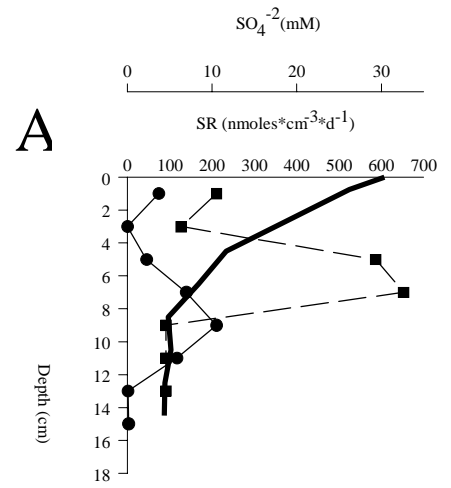

$\mathrm{SO}_{4}^{-2}(\mathrm{mM})$
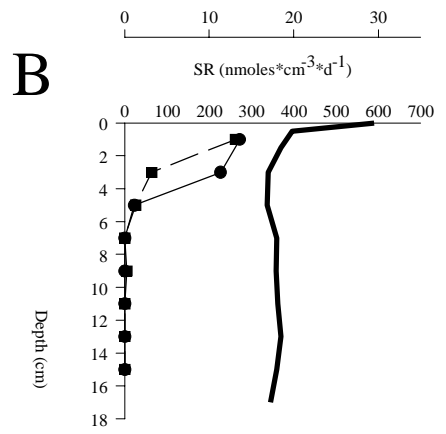

$\mathrm{SO}_{4}^{-2}(\mathrm{mM})$
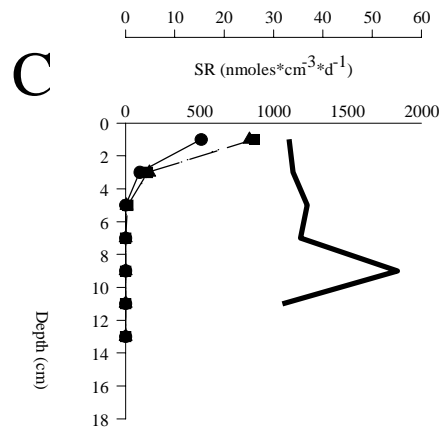

$\mathrm{CH}_{4}(\mathrm{mM})$

$\underbrace{0.00}_{\text {AOM }\left(\text { nmoles }^{*} \mathrm{~cm}^{-3}{ }^{3 *} \mathrm{~d}^{-1}\right)} \begin{array}{llllll}0.05 & 0.10 & 0.15 & 0.20 & 0.25\end{array}$

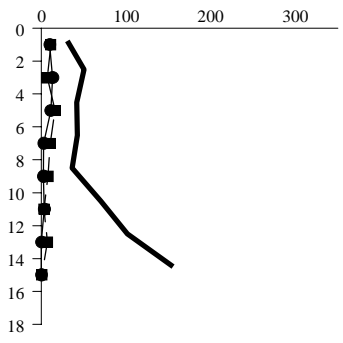

$\mathrm{CH}_{4}(\mathrm{mM})$
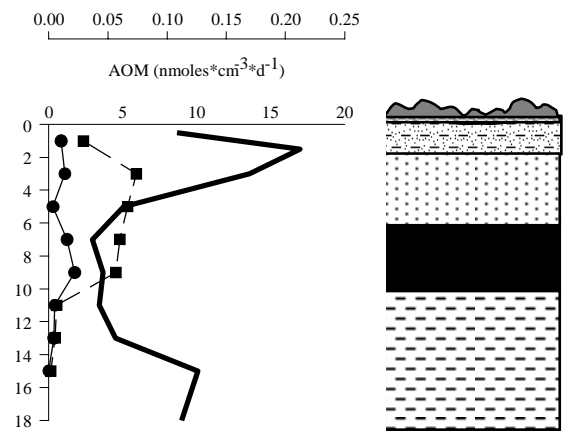

$\mathrm{CH}_{4}(\mathrm{mM})$

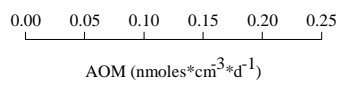

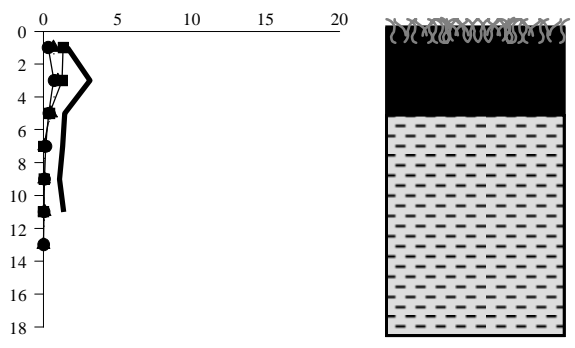

